\title{
Petrografia e geoquímica dos ortoanfibolitos das unidades Novo Gosto e Gentileza, Domínio Canindé, Faixa de Dobramentos Sergipana, Nordeste brasileiro
}

\author{
Leidiane Cerqueira de Carvalho de LIZ ${ }^{1}$, Adriane MACHADO ${ }^{1,2}$, Joaquim Daniel de LIZ $^{2}$ \& Josiene \\ Maria de ALMEIDA ${ }^{1}$
}

${ }^{1}$ Programa de Pós-graduação em Geociências e Análise de Bacias, Universidade Federal de Sergipe. Av. Marechal Rondon, s/n - Jd. Rosa Elze, CEP 49100-000, São Cristóvão, SE, Brasil (leidiane.cerqueira@gmail.com, adrianemachado@yahoo.com.br, josyy42@hotmail.com).

${ }^{2}$ Departamento de Geologia, Universidade Federal de Sergipe. Av. Marechal Rondon, s/n, Jd. Rosa Elze, CEP 49100-000, São Cristóvão, SE, Brasil (joaquimdliz@gmail.com).

Liz, L.C.C., Machado, A., Liz, J.D., Almeida, J.M., 2018. Petrografia e geoquímica dos ortoanfibolitos das unidades Novo Gosto e Gentileza, Domínio Canindé, Faixa de Dobramentos Sergipana, Nordeste brasileiro. Pesquisas em Geociências, 45: e0685.

DOI: https://doi.org/10.22456/1807-9806.88650

\begin{abstract}
Resumo. No Domínio Canindé, situado na porção setentrional da Faixa de Dobramentos Sergipana, nordeste do Brasil, ocorrem rochas metamórficas de protólitos ígneo, que correspondem às unidades Novo Gosto e Gentileza. A difícil definição do ambiente geotectônico de formação e a petrogênese dessas rochas é influenciada pela intensa deformação e metamorfismo, que obliteraram boa parte das feições originais. Este trabalho visa o entendimento dos processos ígneos envolvidos na gênese dos protólitos dos ortoanfibolitos de ambas unidades, apoiados em dados de campo, petrográficos e geoquímicos. Os dados petrográficos sugerem que os ortoanfibolitos das unidades foram metamorfizados no Fácies Anfibolito e sofreram processos retrometamórficos no Fácies Xisto Verde. Apesar do metamorfismo, estas rochas ainda apresentam, ao microscópio, feições ígneas reliquiares. Os dados geoquímicos indicam que o protólito das rochas estudadas da Unidade Novo Gosto corresponde a basaltos de afinidade toleítica, enquanto as da Unidade Gentileza correspondem, em sua maioria, a andesitos e andesitos basálticos com afinidade toleítica à cálcio-alcalina. Com base na interpretação geoquímica, é assumido que as rochas estudadas são basaltos continentais semelhantes a arco, formados em um ambiente de rifte continental com influência de fontes litosféricas subcontinentais com contribuição de componentes tipo OIB, modificadas por subducção prévia e/ou contaminação crustal.
\end{abstract}

Palavras-chave. Rifte, Neoproterozoico, basaltos continentais.

\begin{abstract}
AT CANindé Domain, WHich IS LOCATEd in THE NoRTHERn PORTION OF THE SERGiPANA Fold BELT, NORTHEAST BRAZIL, OCCURS ORTHO-AMPHIBOLITES THAT CORRESPOND TO THE NOVO GOSTO AND GENTILEZA UNITS. The difficult to define the geotectonic environment, as well as the petrogenesis of these rocks is influenced by the intense deformation and metamorphism processes, which oblitered part of the main original features of these rocks. This work aims to understand the igneous processes involved in the genesis of ortho-amphibolites protoliths from both units, based on field, petrographic and geochemical data. The petrographic data suggest that the ortho-amphibolites of these units were metamorphosed in the Amphibolite Facies and they were submitted to retrometamorphic condition processes in the Greenschist Facies. Based on microscopic observations, the othoamphibolites show igneous relics features. The geochemical data indicate that the protolith of from Novo Gosto Unit corresponds to tholeiitic basalts, while those from the Gentileza Unit correspond mainly to andesites and basaltic andesites, with tholeiitic to calc-alkaline affinities. Based on the geochemical interpretations, the studied rocks are arc-like continental basalts, which were formed in a continental rift environment, involving sub-continental lithospheric mantle with contribution of OIB-type components, modified by ancient subduction sources, and/or crustal contamination.

Keywords. Rift, Neoproterozoic, continental basalts.
\end{abstract}




\section{Introdução}

A investigação de rochas ígneas básicas metamorfizadas tem fornecido significativas contribuições na reconstrução da história geológica de áreas complexas. Esses trabalhos têm demonstrado que é possível obter informações importantes relacionadas à gênese, ao tipo de ambiente geotectônico, às características das fontes magmáticas, além de evidenciar os sucessivos eventos de deformação e metamorfismo que afetaram as rochas (Ernst et al., 1991; Menezes Leal et al., 2008; Khalifa et al., 2011).

Desde 1970, diversos estudos petrogenéticos e geoquímicos foram desenvolvidos com o objetivo de caracterizar as diferentes assinaturas dos magmas básicos e correlacioná-las com os respectivos ambientes tectônicos. A partir desses estudos, inúmeros diagramas de discriminação tectônica foram propostos (e.g. Pearce \& Cann, 1973; Pearce \& Norry, 1979; Wood, 1980; Pearce, 1982, 1996, 2008, 2014; Shervais, 1982; Meschede, 1986; Vermeesch, 2006; Verma et al., 2006; Agrawal et al., 2008; Verma \& Agrawal, 2011; Verma \& Oliveira, 2015; Saccani, 2015; Wang et al., 2016; Li et al., 2017), com o intuito de identificar e entender os processos envolvidos na geração e evolução dos magmas e assim desvendar a afinidade tectônica de rochas básicas antigas.

No Domínio Canindé, localizado na porção norte da Faixa de Dobramentos Sergipana (FDS), nordeste do Brasil, ocorrem rochas ígneas máficas metamorfizadas nas unidades Novo Gosto e Gentileza, que representam peças importantes para o entendimento da evolução geológica regional. Devido à complexidade causada pelos processos metamórficos e deformacionais superimpostos nessas rochas, este domínio foi palco de diversas interpretações petrogenéticas e geotectônicas sendo, portanto, considerada uma área intrigante no que se refere à origem e a evolução da FDS (Oliveira et al., 2010).

Neste trabalho são apresentados e discutidos os dados petrográficos e geoquímicos dos ortoanfibolitos das unidades Gentileza e Novo Gosto, com o objetivo de discorrer sobre os processos ígneos envolvidos na geração dos protólitos dessas rochas, de forma a contribuir para o entendimento do ambiente tectônico de formação e dos principais aspectos evolutivos do Domínio Canindé.

\section{2 Área, materiais e métodos}

\subsection{Contexto geológico regional}

A área estudada está situada no sul da Província Borborema, inserida na porção norte da FDS, nordeste do Brasil (Fig. 1A-B). Esta faixa compreende um cinturão orogênico neoproterozoico, com forma triangular e direção WNW-ESE, localizado entre o Cráton São Francisco, a sul, e o Maciço Pernambuco-Alagoas, a norte (Oliveira et al., 2010).

A FDS foi dividida, de norte a sul, em seis domínios litotectônicos distintos: Canindé, Poço Redondo, Marancó, Macururé, Vaza-Barris e Estância (Davison \& Santos, 1989; Silva Filho, 1998; Oliveira et al., 2006). Posteriormente, Oliveira et al. (2010) agruparam os domínios Marancó e Poço Redondo, denominando-os como Domínio Marancó-Poço Redondo, compartimentando a faixa em apenas cinco domínios (Fig. 1B). Cada um dos domínios está limitado, de norte a sul, por zonas de cisalhamento compressionais: Macururé, Belo Monte-Jeremoabo, São Miguel do Aleixo e Itaporanga (Davison \& Santos, 1989; D’el-Rey Silva, 1995; Silva Filho, 1998; Oliveira et al., 2010, 2015).

o Domínio Canindé está situado na região mais setentrional da FDS e suas rochas constituem corpos alongados, de direção NW-SE, paralelo ao Rio São Francisco, com cerca de 4 a 10 km de largura (Fig. 1B). Este domínio limita-se ao sul com o Domínio Poço Redondo pela Zona de Cisalhamento Mulungú-Alto Bonito, que é a extensão oriental da Zona de Cisalhamanto Macururé. A leste, ele está limitado pelo Domínio Macururé, a norte pelo Maciço Pernambuco-Alagoas e a sudoeste, pela cobertura sedimentar da Bacia Tucano-Jatobá.

O Domínio Canindé (Fig. 1C) compreende uma sequência de rochas metassedimentares e metavulcânicas pertencentes à Unidade Novo Gosto, anfibolitos e dioritos intercalados com quartzomonzonitos porfiríticos, além de doleritos e corpos gabroicos, que correspondem a Unidade Gentileza, que é intrudida pelas rochas da Suíte Gabroica Canindé e por granitos diversos (Nascimento, 2005). 
Conforme Oliveira et al. (2010), a Unidade Gentileza apresenta uma íntima associação com os granitos da Suíte Intrusiva Curralinho, com misturas tipo mingling, além de rochas híbridas de composições quartzo monzodioríticas porfiríticas. Aqueles autores incluem no Domínio Canindé a Unidade Garrote, que compreende um sheet granítico fortemente deformado, que é intrusivo na Unidade Novo Gosto.

De acordo com Oliveira et al. (2010), a sedimentação da Unidade Novo Gosto, provavelmente teve início em $715 \mathrm{Ma}$ (idade $\mathrm{U} / \mathrm{Pb}$ em zircão do granito da Unidade Garrote intrusivo na base da sequencia sedimentar), e perdurou até pelo me-
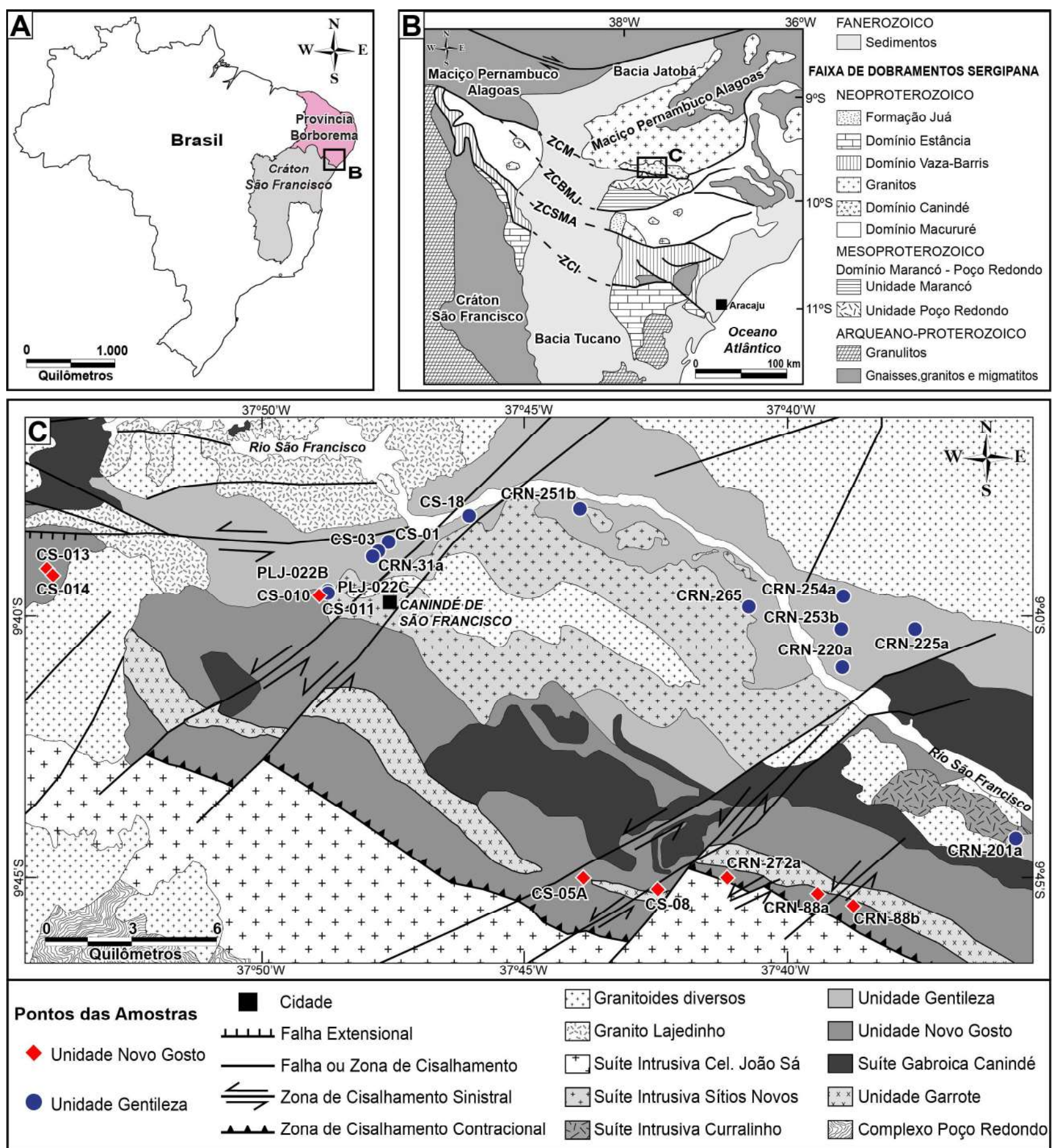

Figura 1. Mapas de localização. A) Localização da FDS em relação ao Cráton São Francisco e a Província Borborema; B) Mapa geológico regional da FDS (modificado de Oliveira et al., 2010). As siglas ZCM, ZCBMJ, CZSMA e ZCI correspondem às zonas de cisalhamento Macururé, Belo Monte-Jeremoabo, São Miguel do Aleixo e Itaporanga, respectivamente; C) Mapa geológico da área estudada, porção central do Domínio Canindé (modificado de Teixeira et al., 2014).

Figure 1. Location Map. A) Sergipano Fold Belt location related to São Francisco Craton and Borborema Province; B) Regional geological map of Sergipano Fold Belt (modified from Oliveira et al., 2010). ZCM, ZCBMJ, ZCSMA and ZCI initials correspond to Macururé, Belo Monte-Jeremoabo, São Miguel do Aleixo and Itaporanga shear zones, respectively; C) Geological map of the studied area, Canindé Domain central portion (modified from Texeira et al., 2014). 
nos 625 Ma (idade do zircão detrítico mais jovem). Dados isotópicos da Suíte Gabroica Canindé indicaram idades de colocação em $690 \pm 16$ Ma pelo método U-Pb (SHRIMP) em zircão (Nascimento, 2005 ) e de $702 \pm 5,5$ Ma por Ar-Ar em flogopita (Brito et al., 2006). As datações obtidas pelo método U-Pb em cristais de zircão de rochas quartzomonzodioríticas da Unidade Gentileza resultaram na idade de $688 \pm 15$ Ma e de $684 \pm 7,3$ Ma para o granito da Suíte Intrusiva Curralinho (Nascimento, 2005; Oliveira et al., 2010). As idades dos granitos mais jovens, intrusivos nessas unidades, variam de $641 \mathrm{Ma}$ a $619 \mathrm{Ma}$, destacando-se o Granito Boa Esperança com $641 \pm 5 \mathrm{Ma}$ (Nascimento, 2005), a Suíte Intrusiva Sítios Novos com $631 \pm 4 \mathrm{Ma}$, a Suíte Intrusiva Coronel João Sá com $625 \pm 2 \mathrm{Ma}$, e o Granito Lajedinho com $619 \pm 3$ Ma (Oliveira et al., 2015), todos obtidos pelo método U-Pb (SHRIMP) em zircão.

\subsection{Interpretações geotectônicas do Domínio Canindé}

Com a evolução do conhecimento sobre a FDS, principalmente em relação a dados geocronológicos e geoquímicos, diversas interpretações têm sido apresentadas para a evolução desta faixa, havendo desde modelos mais antigos, com interpretações relacionadas a um geossinclinal típico (Humphrey \& Allard, 1968; Brito Neves et al., 1977), até o modelo mais atual que propõe um ciclo completo de tectônica de placas durante o Neoproterozoico, com a convergência entre o Cráton São Francisco e o Maciço Pernambuco-Alagoas (Oliveira et al., 2010).

Assim como a FDS, o Domínio Canindé também foi palco de diversas interpretações quanto ao ambiente geotectônico e petrogenético. Uma das primeiras interpretações deve-se a Silva Filho (1976), que interpretou esse domínio como um complexo ofiolítico. Jardim de Sá et al. (1986) e Silva Filho (1998) sugeriram um ambiente de arco de ilha. Oliveira \& Tarney (1990) interpretaram este domínio como o registro de um magmatismo intracontinental e ressaltaram a similaridade, tanto dos gabros quanto dos anfibolitos ortoderivados das unidades Gentileza e Novo Gosto, com basaltos continentais da Bacia do Paraná. Bezerra (1992) sugeriu um ambiente anorogênico intracontinental para a formação do Domínio Canindé. Outra interpretação foi apresentada por Nascimento (2005) que, com base em relações de campo, geoquímica e dados isotópicos, sugeriu que a sequência de rochas do Domínio Canindé foi gerada em um ambiente de rifte continental. Oliveira et. al. (2010) sustentam as interpretações de que o Domínio Canindé representa um ambiente de rifte continental que teve início em cerca de 715 Ma com a geração de um magmatismo bimodal. A Unidade Garrote e as rochas vulcânicas máficas continentais da Unidade Novo Gosto tiveram origem durante os estágios iniciais de abertura, seguidos pela geração da Suíte Gabroica Canindé ( 700 Ma), dos microgabros e quartzo-monzonitos da Unidade Gentileza (688 Ma) e da Suíte Intrusiva Curralinho (684 Ma). Já nos estágios finais de abertura, o Granito Boa Esperança (641 Ma) foi gerado. Aqueles autores consideraram a possibilidade do rifte ter evoluído para uma bacia oceânica, em função da presença de anfibolitos intercalados com lentes de mármore e pela ocorrência de basaltos com estruturas em pillows na Unidade Novo Gosto; sugerem ainda que o fechamento desta bacia teria iniciado em torno de $630 \mathrm{Ma}$, com a intrusão dos granitos mais jovens com assinatura de arco continental. Verma \& Oliveira (2015) reacenderam a discussão, com a publicação de um estudo geoquímico baseado em diagramas discriminantes multidimensionais, nos quais sugerem que os ortoanfibolitos da Unidade Gentileza foram gerados em ambiente de arco a rifte continental, enquanto que os ortoanfibolitos da Unidade Novo Gosto teriam se formado em ambiente de arco de ilha. Por fim, Passos (2016) reinterpretou os dados geoquímicos obtidos por Nascimento (2005) para os ortoanfibolitos da Unidade Novo Gosto e sugeriu que os protólitos ígneos dessa unidade foram formados em um ambiente de zona de supra-subducção, enquanto que o material sedimentar teria sido originado em uma bacia de margem passiva.

\subsection{Geologia local}

\subsubsection{Ortoanfibolitos - Unidade Novo Gosto}

As rochas da Unidade Novo Gosto estendem-se ao longo de uma faixa descontínua (NW- 
$\mathrm{SE}$ ), com aproximadamente $45 \mathrm{~km}$ de comprimento e 3 a $7 \mathrm{~km}$ de largura. As rochas de filiação ígnea presentes nessa unidade ocorrem de duas formas principais: uma predominante, que ocorre como corpos tabulares centimétricos a métricos intercalados com metacherts, metamargas, mármores e xistos; e outra que ocorre na forma de diques. No primeiro caso, devido ao intenso metamorfismo e deformação impressos, não é possível assumir, com clareza, se originalmente eram rochas efusivas ou intrusivas do tipo soleira. Macroscopicamente, essas rochas são representadas por anfibolitos de coloração cinza escuro a esverdeado, com foliação fraca e textura fina (Fig. 2A e B). A mineralogia essencial dessas rochas é composta por anfibólio e plagioclásio, com variados conteúdos de biotita, clorita e epídoto. Venulações oblíquas à orientação principal (N130/85), preenchidas por calcita e/ou epídoto, são observadas nessas rochas, principalmente nas proximidades dos granitoides tardios.

Os diques ocorrem na porção oeste da área, próximo a Unidade Gentileza, onde intrudem um corpo metasienogranítico. Nesta condição, as rochas apresentam-se menos deformadas, sendo possível observar claramente os contatos sinuosos com o metasienogranito, além de feições ígneas reliquiares marcadas por cristais ripidiformes de plagioclásio, que estão imersos em uma matriz equigranular fina, de coloração cinza escuro.

\subsubsection{Ortoanfibolitos - Unidade Gentileza}



Figura 2. Aspectos de campo de rochas da Unidade Novo Gosto. A) Afloramento de ortoanfibolito da Unidade Novo Gosto; B) Textura equigranular de granulação fina representativa do ortoanfibolito da Unidade Novo Gosto.

Figure 2. Field aspect of Novo Gosto Unit rocks. A) Ortho-amphibolite outcrop of Novo Gosto Unit; B) Ortho-amphibolite Novo Gosto Unit showing fine-grained and equigranular textures.
As rochas máficas da Unidade Gentileza ocorrem como anfibolitos com aspecto maciço a pouco foliado, com coloração variando de cinza escuro à verde escuro e textura equigranular fina a média (Figs. 3A-B). Macroscopicamente é possível observar mineralogia composta principalmente por plagioclásio, anfibólio e biotita.

A filiação ígnea dos ortoanfibolitos da Unidade Gentileza é destacada pelas feições de misturas tipo mingling e mixing, evidenciadas por interações entre termo máfico (ortoanfibolito) e termo félsico, representado por metasienogranito de afinidade alcalina (Nascimento et al., 2017) (Fig. 3A). Nas porções em que há o predomínio da rocha félsica, a rocha máfica ocorre na forma de corpos intrusivos tabulares, com contatos interdigitados a localmente retos. Nessas porções, a textura fina é predominante e evidencia um resfriamento mais rápido do termo máfico em contato com a rocha félsica de granulação grossa. Em porções onde o volume de rocha máfica é maior que o volume de rocha félsica, observa-se maior interação entre esses termos, sendo comum a presença de misturas tipo mixing, com geração de rochas híbridas. Ainda nessas porções, ocorre a presença de feições co-mingling, evidenciadas por enclaves máficos envolvidos por rochas híbridas.

Um modelamento geoquímico realizado na Unidade Gentileza identificou rochas híbridas formadas por misturas, com participações de $18 \%$ a $30 \%$ de rocha félsica e $70 \%$ a $82 \%$ de rochas máficas (Nascimento et al., 2017). 


\subsection{Materiais e métodos}

Durante os trabalhos de campo foram descritos 24 afloramentos, abrangendo observações quanto aos contatos geológicos, presença de estruturas primárias (ígneas) e secundárias (tectônicas), identificação de texturas e mineralogia, além da coleta de 30 amostras de rocha.

A partir das amostras coletadas foram confeccionadas 17 lâminas delgadas, para análise petrográfica em luz transmitida, das quais 10 lâminas representam as rochas estudadas. Estas seções delgadas foram confeccionadas no Laboratório de Laminação da Universidade de Brasília (UnB). As descrições petrográficas foram realizadas utilizando-se o microscópio Olympus BX41 do Laboratório de Microscopia e Lupas do Departamento de Geologia, Universidade Federal de Sergipe.

Para análise de composições químicas de elementos maiores, traço e terras raras (ETR), um conjunto de 14 amostras foi analisado. Deste conjunto, 11 amostras foram utilizadas neste trabalho. As amostras foram preparadas e analisadas no SGS-Geosol Laboratórios Ltda., em Minas Gerais, utilizando-se a técnica de ICP-OES (Inductively Coupled Plasma Optical Emission Spectrometry) para elementos maiores e cromo, e ICP-MS (Inductively Coupled Plasma Mass Spectrometry) para elementos-traço e terras raras. Os limites de detecção para a maioria dos elementos maiores ficaram na ordem de $0,01 \%$ e de 0,1 ppm para elementostraço. A maior parte dos dados químicos foram tratados em diagramas elaborados no software GCDkit (Geochemical Data Toolkit for Windows), versão 4.1.

\section{Resultados}

\subsection{Aspectos Petrográficos}

\subsubsection{Unidade Novo Gosto}

O estudo petrográfico revelou que os ortoanfibolitos da Unidade Novo Gosto são compostos por plagioclásio (29-39\%), hornblenda (35-25\%), biotita (6-13\%), clorita (7-16\%), epídoto (8-12 $\%)$, sericita (3-13\%), quartzo (2-3\%) e minerais opacos (3-8 \%), além de apatita e zircão $(<1 \%)$. $\mathrm{Na}$ área estudada, é comum a presença de porções em que a mineralogia de baixo grau metamórfico é dominante, devido às intensas transformações retrometamórficas sofridas. Entretanto, localmente, feições ígneas reliquiares ainda são observadas.

0 plagioclásio é o mineral mais abundante nas rochas estudadas; apresenta-se nos interstícios da hornblenda, com formas subidioblásticas a xenoblásticas e dimensões de 0,03 a 0,35 mm. Possui contatos irregulares (curvos e interlobados) com hornblenda e minerais opacos, sendo frequentemente observadas transformações parciais para

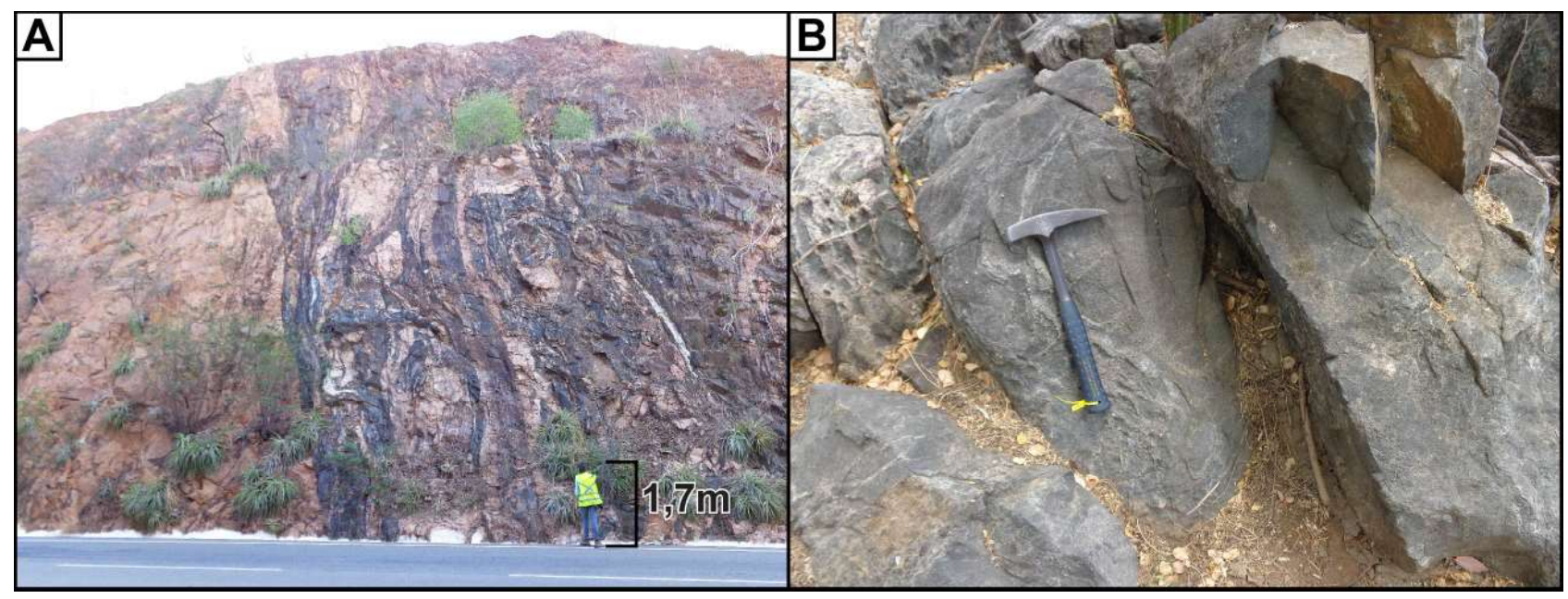

Figura 3. Aspectos de campo de rochas da Unidade Gentileza. A) Panorama fotográfico do afloramento da Unidade Gentileza na rodovia SE-200 evidenciando as interações entre termo máfico (ortoanfibolito) e félsico (metasienogranito), que são marcadas por feições mingling com interdigitações complexas, com porções hibridizadas localizadas; B) Afloramento típico da Unidade Gentileza caracterizado pela ocorrência de ortoanfibolito com textura equigranular média.

Figure 3. Field aspect of Gentileza Unit rocks. A) Photographic view of Gentileza Unit outcrop at SE-200 highway showing interactions between mafic (ortho-amphibolite) and felsic portions (metasyenogranite), which are avidencied by mingling with complex interdigitaions and located hybridized portions; B) Typical Gentileza Unit ortho-amphibolite outcrop with medium-grained and equigranular textures. 
sericita e, por vezes, para epídoto. Feições ígneas reliquiares são observadas, localmente, em porfiroclastos de plagioclásio, formando texturas blasto-glomeroporfiríticas, com cristais variando entre 0,5 e 2,0 mm e, ocasionalmente, com zonação bem desenvolvida (Fig. 4A). Estes grãos apresentam geminação polissintética do tipo albita, com teor de anortita, estimado pelo método de Michel-Lévy, em torno de 48-52\%, sendo classificado como andesina e labradorita. Nessas rochas são também observadas as texturas blasto-ofítica, blasto-subofítica e blasto-integranular (Fig. 4B e D), indicativas de um protólito ígneo máfico.

A hornblenda, segundo mineral mais abundante nestes litotipos, ocorre com forma xenoblástica a subidioblástica, com dimensões que variam de 0,05 a 0,4 mm e pleocroísmo em tons esverdeados a amarelados; com frequência ocorre parcialmente transformado para epídoto, biotita e/ou clorita. Os grãos possuem contatos interlobados e curvos com o plagioclásio, além da presença de inclusões de apatita e minerais opacos. No geral, a orientação deste mineral confere às rochas estudadas a textura nematoblástica (Fig. 4C).

A biotita ocorre com pleocroísmo variando entre o castanho claro e castanho escuro, formas xenoblásticas e tamanho de cristal variando entre 0,02 e 0,25 mm. Este mineral ocorre, em algumas porções, substituindo as bordas da hornblenda. Observa-se a presença de minerais opacos inclusos nesta fase mineral ou em contato com os limites dos grãos.

A ocorrência de quartzo é restrita as rochas com alterações mais intensas. Nestas, os cristais são xenoblásticos e ocupam os interstícios dos cristais de hornblenda e plagioclásio.

0 epídoto ocorre, de forma caótica, disseminado na rocha, associado à clorita e biotita, e substituindo a hornblenda e o plagioclásio. Os cristais variam de subidioblásticos a xenoblásticos, com dimensões inferiores a 0,01 , por vezes até $0,3 \mathrm{~mm}$. De forma similar, a sericita ocorre com granulação muito fina, como produto da alteração do plagioclásio.

A clorita ocorre disseminada na rocha, substituindo os grãos de hornblenda da matriz. Esta fase ocorre, principalmente, de forma caótica, com coloração verde claro, com formas xenoblás- ticas e dimensões variando de 0,01 a 0,1 mm. Nos litotipos em que esta fase predomina, a clorita contém textura lepidoblástica e formas subidioblásticas a xenoblásticas e dimensões inferiores a 0,1 $\mathrm{mm}$.

Os minerais opacos ocorrem na forma de grãos subdioblásticos a xenoblásticos, com tamanhos em torno de 0,2 a $0,3 \mathrm{~mm}$, preferencialmente, inclusos na hornblenda e biotita.

Os minerais acessórios, tais como apatita e zircão, ocorrem disseminados na rocha. A apatita é comumente idioblástica, enquanto o zircão é xenoblástico.

A análise microscópica demonstrou que as rochas máficas metamorfizadas da Unidade Novo Gosto possuem mineralogia metamórfica da Fácies Anfibolito marcada por hornblenda e plagioclásio. A mineralogia da Fácies Anfibolito foi, em parte, transformada para uma paragênese da Fácies Xisto Verde, composta principalmente por clorita, biotita, epídoto e sericita. Essas constatações corroboram com os dados obtidos por Passos (2016), que envolveram estudos geotermobarométricos em rochas dessa unidade.

\subsubsection{Unidade Gentileza}

Ao microscópio, os ortoanfibolitos da Unidade Gentileza têm textura equigranular média a fina, são compostos principalmente por hornblenda (28-51\%) e plagioclásio (34-38\%), além de biotita (20-24\%), sericita (0-5\%), quartzo (0-3 $\%)$, clorita (0-2\%), titanita (3-5\%), apatita (1-5 $\%)$, minerais opacos (1-4\%), epídoto $(<1 \%)$ e zircão $(<1 \%)$.

A hornblenda, que representa o principal constituinte destas rochas, ocorre na forma de grãos subidioblásticos e xenoblásticos, com dimensões variando entre 0,01 a 4 mm e pleocroísmo variando de castanho a verde oliva. Por vezes, é possível observar a presença da textura nematoblástica, marcada pela orientação da hornblenda, além da textura blasto-subofítica, definida por grãos de hornblenda que envolvem parcialmente grãos de plagioclásio. De forma restrita, a hornblenda aparece substituída por clorita, onde esta fase apresenta coloração verde claro, com formas xenoblásticas. 


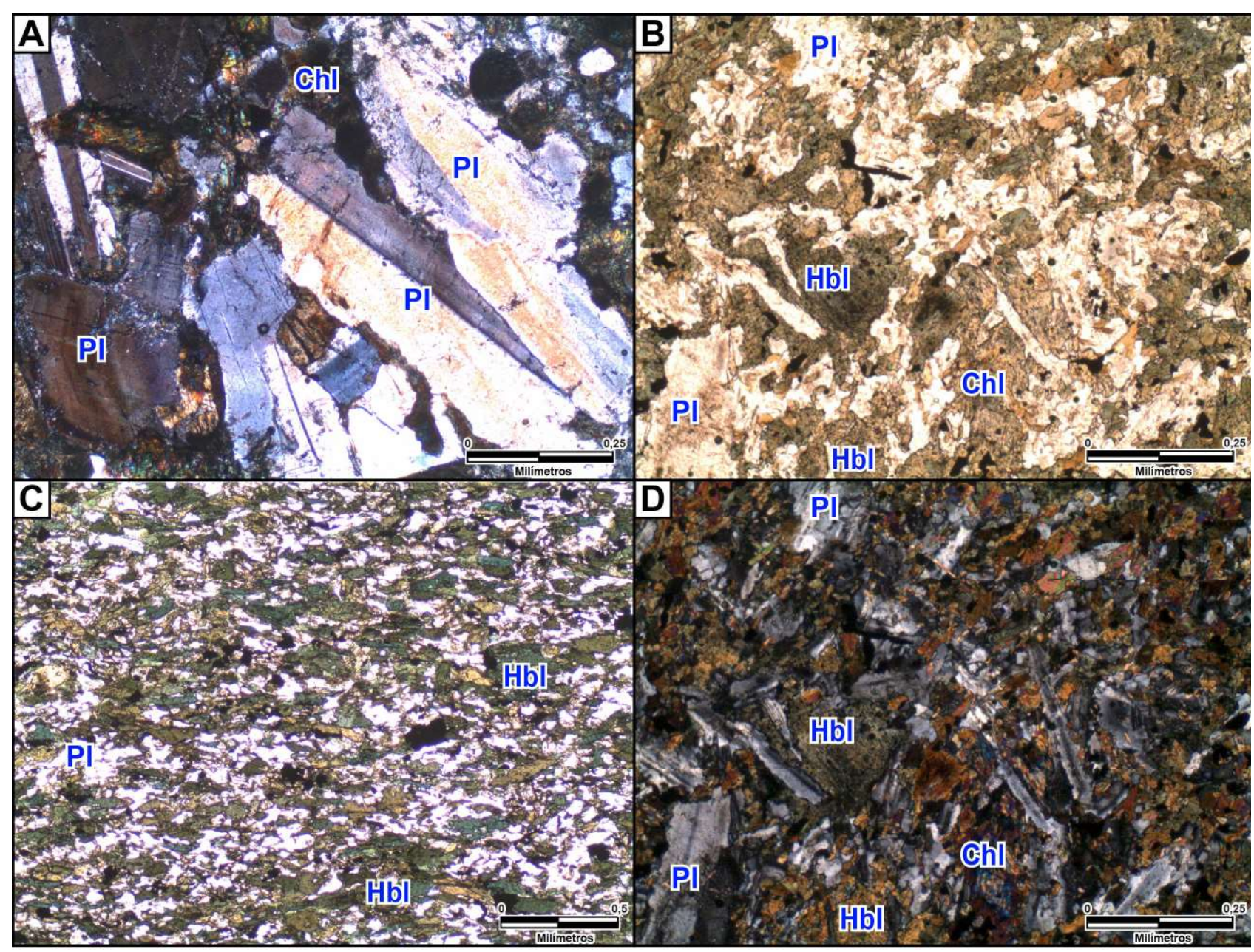

Figura 4. Aspectos microscópicos dos ortoanfibolitos da Unidade Novo Gosto. A) Textura blasto-glomeroporfirítica de plagioclásio, com a presença de grão zonado na porção inferior esquerda da fotomicrografia (luz polarizada); B e D) Texturas blasto-integranular e blasto-subofítica marcadas por cristais ripidiformes de plagioclásio isotrópicos, parcialmente envolvidos por cristais de hornblenda (luz natural e luz polarizada); C) Textura nematoblástica marcada pela orientação dos grãos de hornblenda (luz natural). Siglas: $\mathrm{Pl}=$ plagioclásio, $\mathrm{Hbl}=$ hornblenda, $\mathrm{Chl}=$ clorita.

Figure 4. Microscopic aspects of Novo Gosto Unit ortho-amfibolites. A) Blasto-glomeroporphiritic texture of plagioclase with a zoned grain at lower left portion of the photomicrography (polarized light); B and D) Blasto-integranular and blasto-subophytic texture marked by ripidiform plagioclase with isotropic orientation, surrounded by hornblende (natural and polarized light); C) Nematoblastic texture marked by the oriented hornblende grains (natural light). $\mathrm{Pl}=$ plagioclase, $\mathrm{Hbl}=$ hornblende, $\mathrm{Chl}=\mathrm{chlorite}$.

Os cristais de plagioclásio apresentam formas subdioblástica e xenoblástica, com dimensões que variam de 0,05 a $1,5 \mathrm{~mm}$. Este mineral ocorre nos interstícios da hornblenda, com contatos irregulares com a biotita, sendo comum a presença de sericita como produto de alteração. Feições ígneas reliquiares são marcadas por porfiroclastos desta fase, que definem a textura blasto-subofítica, como pode ser observado nas figuras $5 \mathrm{~A}$ e B. Estes grãos apresentam teor de anortita em torno de $36-51 \%$, sendo classificados como andesina a labradorita, de acordo com o Método de Michel-Lévy.

A biotita ocorre com formas idioblásticas a subidioblásticas, com dimensões que variam de 0,03 a $0,8 \mathrm{~mm}$ e pleocroísmo amarelo pálido a castanho escuro. Esta fase apresenta-se em equilíbrio com a hornblenda, por vezes, como produto de al- teração desta (Fig. 5A e B).

0 quartzo ocorre com forma xenoblástica, com dimensões variando entre 0,05 e $0,15 \mathrm{~mm}$, e comumente disseminado entre os cristais de plagioclásio. Nesta fase é comum a presença de feições deformacionais de baixa temperatura em rochas próximas a zonas de cisalhamento, tais como extinção ondulante e subgrãos (Fig. 5C e D).

A titanita ocorre, principalmente, como produto da transformação das bordas de minerais opacos xenoblásticos, e menos comumente, como cristais individuais (Fig. 5C e D). Este mineral apresenta formas xenoblásticas e dimensões entre 0,02 e $0,3 \mathrm{~mm}$, enquanto os minerais opacos possuem dimensões de 0,03 a 0,8 mm; aparecem inclusos na hornblenda, na biotita e no plagioclásio.

A apatita ocorre disseminada em toda a ro- 
cha, com formas prismáticas e tamanho inferior a $0,2 \mathrm{~mm}$. 0 zircão apresenta cristais subidioblásticos a xenoblásticos, com dimensões de 0,05 e 0,1 mm e feições metamitizadas.

$\mathrm{Na}$ mineralogia secundária observam-se cristais de epídoto, que ocorrem, localmente, substituindo parte dos grãos de hornblenda. Esta fase mineral apresenta forma xenoblástica e dimensões que variam de 0,03 a $0,4 \mathrm{~mm}$.

A mineralogia dos ortoanfibolitos da Unidade Gentileza, quando comparados à mineralogia dos ortoanfibolitos da Unidade Novo Gosto, apresenta-se mais preservada, com maiores volumes de biotita distribuídos em toda a rocha, além de possuírem maiores volumes de minerais acessórios (titanita, apatita e zircão). Entretanto, os ortoanfibolitos da Unidade Novo Gosto estão mais alterados, com predominância da mineralogia de mais baixo grau metamórfico.

\subsection{Geoquímica}

Neste trabalho foram utilizadas 22 análises de rocha total, sendo 11 geradas neste estudo, representadas pelas iniciais CS e PLJ e outras 11 obtidas por Nascimento (2005), representadas pelas iniciais CRN (Tab. 1 e 2). Estes dados geoquímicos foram utilizados com a finalidade de identificar a afinidade e o comportamento geoquímico dos elementos analisados, investigar os processos magmáticos envolvidos durante a evolução das rochas estudadas, bem como o provável ambiente tectônico, e assim obter subsídios geológicos que possibilitem discutir a possível natureza da fonte.

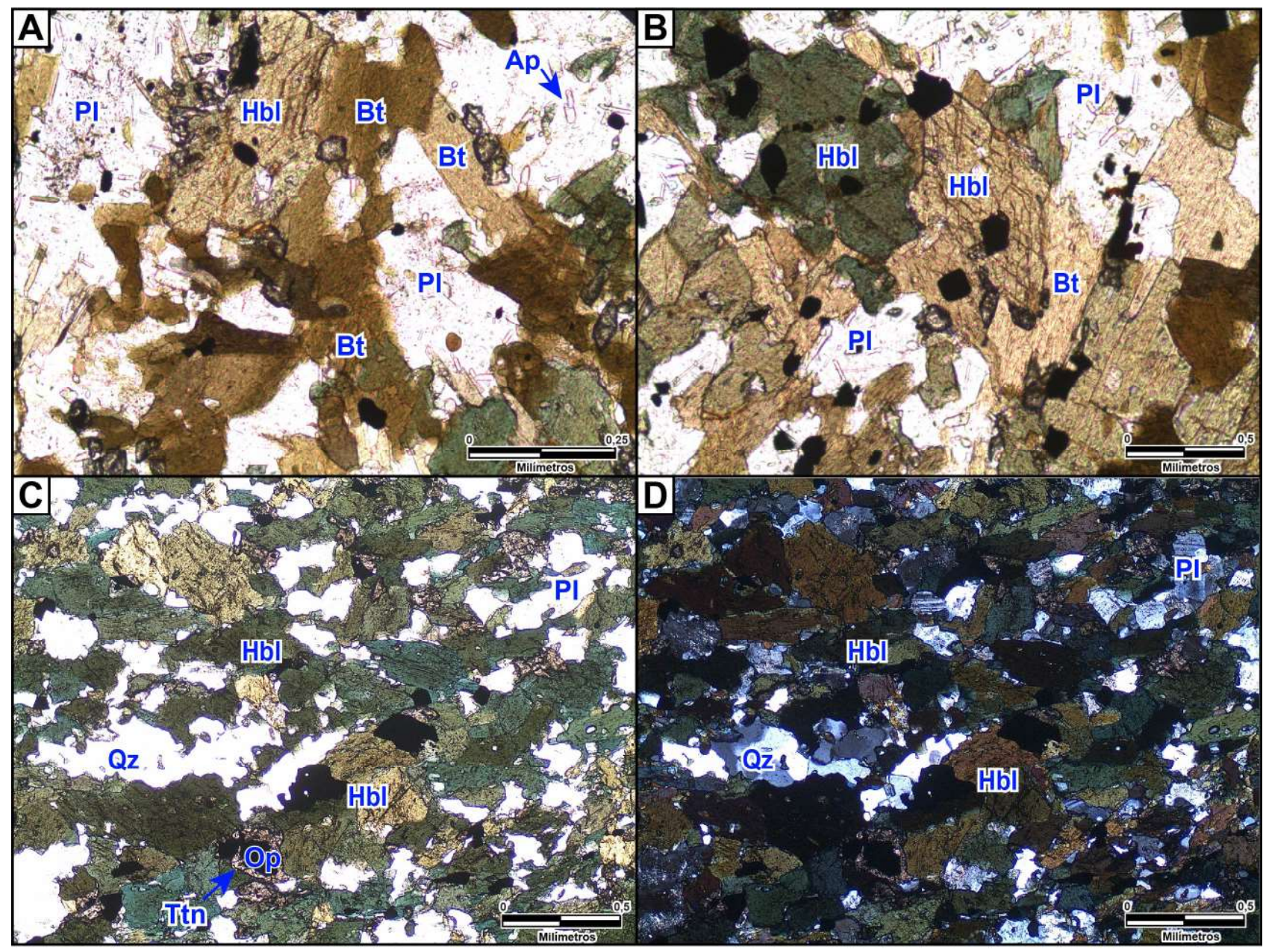

Figura 5. Aspectos microscópicos dos ortoanfibolitos da Unidade Gentileza. A) Detalhe de cristal de hornblenda com borda substituída por biotita (luz natural); B) Detalhe de mineral opaco com transformação nas bordas para titanita (luz natural); C e D) Detalhe de textura nematoblástica marcada pela orientação incipiente de grãos de hornblenda e plagioclásio, com presença de subgrãos de quartzo (luz natural e polarizada). Siglas: $\mathrm{Pl}=$ plagioclásio, $\mathrm{Hbl}=$ hornblenda, $\mathrm{Op}=$ minerais opacos, $\mathrm{Ttn}=\mathrm{tita}-$ nita, $\mathrm{Bt}=$ biotita, $\mathrm{Qz}=$ quartzo, $\mathrm{Ap}=$ apatita.

Figure 5. Microscopic aspects of Gentileza Unit ortho-amfibolites. A) Detail of hornblende showing edge replaced by biotite (natural light); B) Detail of opaque mineral with titanite transformation in the edges (natural light); C and D) Detail of nematoblastic texture marked by incipient orientation of hornblende and plagioclase, with presence of subgrain quartz (natural and polarized light). $\mathrm{Pl}=$ plagioclase, $\mathrm{Hbl}=$ hornblende, $\mathrm{Op}=$ opaque mineral, $\mathrm{Ttn}=$ titanite, $\mathrm{Bt}=$ biotite, $\mathrm{Qz}=\mathrm{quartz}, \mathrm{Ap}=$ apatite . 


\subsubsection{Avaliação da mobilidade dos elementos}

No estudo geoquímico de protólitos ígneos de rochas metamórficas é necessário, primeiramente, avaliar a mobilidade dos elementos, para entender os efeitos das transformações metamórficas sobre as composições químicas. 0 zircônio em protólitos ígneos máficos é geralmente considerado o elemento mais imóvel durante as alterações hidrotermais e metamorfismo de baixo e médio grau (Pearce \& Cann, 1973; Weaver \& Tarney, 1981; Sheraton, 1984; Li et al., 2008; Pearce, 2014). Processos de contaminação crustal e mistura de magmas podem interferir na distribuição dos elementos químicos e estes devem ser considerados na avaliação de mobilidade de elementos.

Elementos de diferentes comportamentos químicos, como $\mathrm{Nb}, \mathrm{Hf}, \mathrm{Ta}, \mathrm{Y}, \mathrm{Ce}, \mathrm{Sm}, \mathrm{TiO}_{2}, \mathrm{Th}, \mathrm{V}$, $\mathrm{Rb}$, Sr e Ba, foram plotados contra o $\mathrm{Zr}$, para avaliar a mobilidade destes elementos nas amostras das unidades Novo Gosto e Gentileza (Fig. 6). Nestas, os Elementos de Alto Potencial Iônico (HFSEs, como $\mathrm{Nb}$, Hf e Ta) e os ETRs apresentam fortes correlações com Zr, sugerindo que estes elementos permaneceram imóveis durante o metamorfismo. Os Elementos Litófilos de Grande Raio Iônico
(LILEs), representados por $\mathrm{Rb}, \mathrm{Sr}$ e $\mathrm{Ba}$, mostram maior dispersão em relação ao $\mathrm{Zr}$, implicando diferentes graus de mobilidade durante o metamorfismo. Os elementos Th e $\mathrm{V}$ apresentam uma pequena dispersão, que é interpretada como variações devido aos processos de contaminação crustal e/ou misturas de magmas.

A partir da avaliação da mobilidade dos LILEs, HFSEs e ETRs foi possível identificar os elementos imóveis durante o metamorfismo, e assim selecionar os elementos a serem utilizados na classificação e discussões petrogenéticas.

\subsubsection{Litoquímica da Unidade Gentileza}

Para avaliar o comportamento geoquímico dos ortoanfibolitos da Unidade Gentileza, as amostras foram plotadas em diagramas geoquímicos de classificação e nomenclatura de rocha. Os dados litoquímicos utilizados nestes diagramas são apresentados na tabela 1.

No diagrama de classificação $\mathrm{Nb} / \mathrm{Y}$ vs $\mathrm{Zr} /$ Ti (Pearce, 1996), o protólito dos ortoanfibolitos da Unidade Gentileza correspondem, em grande maioria, a andesito e andesito basáltico, com exceção para duas amostras (CRN-31A e CS-01), que
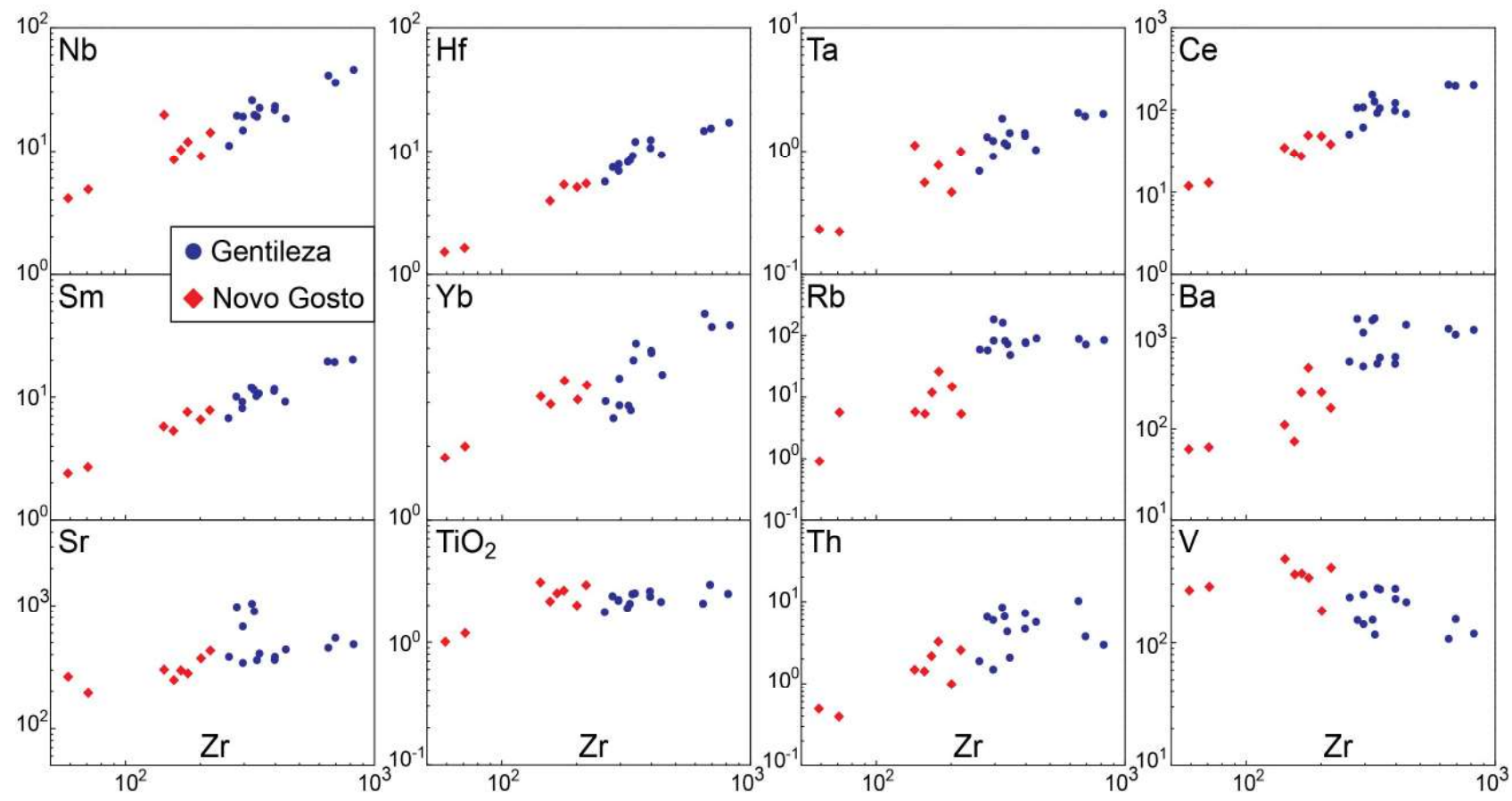

Figura 6. Comparação de elementos traço versus Zr, para avaliação da mobilidade desses elementos nos ortoanfibolitos das unidades Novo Gosto e Gentileza.

Figure 6. Trace elements versus Zr plots to evaluate the elements mobility in ortho-amphibolites from Novo Gosto and Gentileza units. 
Tabela 1. Composições químicas de elementos maiores, traços e terras raras de amostras representativas da Unidade Gentileza, no Domínio Canindé. Abreviação: P.F.= Perda ao fogo; n.d.= Não determinado.

Table 1. Chemical compositions of major, trace and rare earth elements of representative samples from Gentileza unit, Canindé Domain. Abbreviation: P.F.= Loss on ignition; n.d.= not determined.

\begin{tabular}{|c|c|c|c|c|c|c|c|c|c|c|c|c|c|c|}
\hline & \multicolumn{14}{|c|}{ Unidade Gentileza } \\
\hline & CS-01 & CS-03 & CS-018 & PLJ-022B & PLJ-022C & CS-11 & CRN-31a & CRN201a & CRN-220: & CRN-225a & CRN-251b & CRN-253b & CRN-254a & CRN-265 \\
\hline $\mathrm{SiO}_{2}(\%)$ & 53,77 & 56,04 & 52,82 & 57,19 & 50,32 & 49,79 & 54,81 & 48,38 & 51,43 & 48,82 & 49,75 & 49,46 & 49,35 & 48,74 \\
\hline $\mathrm{TiO}_{2}$ & 2,38 & 2,06 & 2,14 & 2,07 & 2,49 & 2,95 & 1,90 & 1,76 & 2,36 & 2,48 & 2,22 & 2,51 & 2,19 & 2,61 \\
\hline $\mathrm{Al} 2 \mathrm{O}_{2}$ & 14,65 & 15,05 & 15,60 & 14,95 & 15,14 & 14,42 & 14,94 & 16,30 & 14,68 & 14,34 & 15,36 & 15,18 & 15,21 & 14,85 \\
\hline $\mathrm{Fe}_{2} \mathrm{O}_{2}$ & 10,51 & 9,65 & 10,78 & 10,45 & 11,80 & 12,66 & 9,38 & 10,67 & 11,53 & 13,03 & 12,03 & 12,52 & 11,92 & 13,24 \\
\hline $\mathrm{MnO}$ & 0,15 & 0,15 & 0,19 & 0,18 & 0,21 & 0,24 & 0,15 & 0,19 & 0,18 & 0,20 & 0,18 & 0,19 & 0,18 & 0,19 \\
\hline $\mathrm{MgO}$ & 4,44 & 3,99 & 5,47 & 2,54 & 3,07 & 4,15 & 3,89 & 7,29 & 4,86 & 6,41 & 6,10 & 5,20 & 6,04 & 5,68 \\
\hline $\mathrm{CaO}$ & 5,91 & 5,22 & 7,07 & 5,04 & 5,86 & 6,98 & 5,58 & 8,68 & 7,36 & 8,38 & 8,13 & 8,37 & 8,07 & 7,64 \\
\hline $\mathrm{Na}_{2} \mathrm{O}$ & 3,80 & 3,54 & 3,17 & 3,71 & 3,62 & 3,84 & 3,91 & 2,68 & 3,86 & 3,17 & 3,18 & 3,41 & 3,16 & 3,12 \\
\hline $\mathrm{K}_{2} \mathrm{O}$ & 2,70 & 3,17 & 2,39 & 2,86 & 2,69 & 2,41 & 3,28 & 2,48 & 1,99 & 1,81 & 1,79 & 1,60 & 1,78 & 2,04 \\
\hline $\mathrm{P}_{2} \mathrm{O}_{5}$ & 0,81 & 0,96 & 0,46 & 0,97 & 1,13 & 1,75 & 0,83 & 0,36 & 0,65 & 0,56 & 0,42 & 0,62 & 0,42 & 0,61 \\
\hline $\mathrm{Cr}_{2} \mathrm{O}_{3}$ & 0,02 & $<0,01$ & 0,01 & $<0,01$ & $<0,01$ & $<0,01$ & n.d & n.d & n.d & n.d & n.d & n.d & n.d & n.d \\
\hline P.F. & 0,88 & 2,23 & 1,93 & 0,64 & 0,40 & 0,62 & 0,32 & 1,52 & 0,79 & 0,79 & 1,06 & 0,58 & 1,40 & 1,16 \\
\hline Total & 100,02 & 102,06 & 102,01 & 100,58 & 96,72 & 99,81 & 98,99 & 100,31 & 99,69 & 99,99 & 100,22 & 99,64 & 99,71 & 99,88 \\
\hline $3 a(p p m)$ & 1604 & 1627 & 1386 & 1254 & 1218 & 1079 & 1554 & 549 & 617 & 521 & 486 & 607 & 1137 & 519 \\
\hline $\mathrm{Rb}$ & 57,30 & 81,80 & 89,60 & 87,70 & 84,30 & 71,50 & 160,00 & 59,00 & 75,00 & 72,78 & 82,54 & 48,15 & 181,67 & 77,58 \\
\hline $\mathrm{Sr}$ & 981 & 903 & 442 & 456 & 487 & 550 & 1040 & 385 & 385 & 362 & 343 & 409 & 680 & 364 \\
\hline Th & 6,60 & 6,70 & 5,70 & 10,30 & 3,00 & 3,80 & 8,60 & 1,90 & 7,30 & 4,38 & 1,50 & 2,10 & 6,02 & 4,71 \\
\hline $\mathrm{U}$ & 1,31 & 1,46 & 1,65 & 2,30 & 0,99 & 1,30 & 4,90 & 0,71 & 1,96 & 1,39 & 1,12 & 1,77 & 2,28 & 1,28 \\
\hline $\mathrm{Zr}$ & 280 & 329 & 440 & 651 & 822 & 695 & 322 & 260 & 398 & 337 & 296 & 345 & 296 & 397 \\
\hline $\mathrm{Hf}$ & 7,29 & 8,32 & 9,24 & 14,47 & 16,90 & 15,15 & 8,06 & 5,59 & 12,23 & 9,08 & 7,71 & 11,83 & 6,80 & 10,54 \\
\hline $\mathrm{Nb}$ & 19,43 & 19,73 & 18,48 & 41,20 & 45,80 & 35,94 & 25,88 & 11,11 & 23,21 & 19,10 & 14,80 & 22,48 & 19,08 & 21,61 \\
\hline Y & 26,83 & 30,27 & 37,56 & 69,27 & 67,51 & 62,40 & 32,00 & 31,00 & 51,27 & 46,29 & 39,40 & 53,32 & 32,67 & 51,83 \\
\hline $\mathrm{Ta}$ & 1,30 & 1,16 & 1,02 & 2,04 & 2,00 & 1,91 & 1,83 & 0,68 & 1,33 & 1,11 & 0,90 & 1,40 & 1,21 & 1,40 \\
\hline $\mathrm{Cr}$ & n.d & n.d & n.d & n.d & n.d & $\mathrm{n}, \mathrm{d}$ & 105 & 23 & 89 & 53 & 18 & 26 & 73 & 57 \\
\hline $\mathrm{Ni}$ & 79 & 59 & 74 & 9 & 11 & 12 & 39 & 78 & 23 & 57 & 67 & 29 & 147 & 47 \\
\hline V & 152 & 116 & 213 & 107 & 118 & 155 & 153 & 233 & 227 & 277 & 246 & 271 & 141 & 274 \\
\hline La & 49,90 & 58,10 & 46,80 & 89,80 & 86,70 & 86,60 & 69,09 & 29,00 & $\begin{array}{l}48,00 \\
119,0\end{array}$ & 42,00 & 24,00 & 35,63 & 43,37 & 37,00 \\
\hline $\mathrm{Ce}$ & 104,60 & 123,80 & 88,60 & 197,10 & 195,20 & 191,4 & 149,77 & 49,74 & 4 & 90,61 & 60,52 & 103,00 & 105,80 & 96,42 \\
\hline $\operatorname{Pr}$ & 12,84 & 14,74 & 11,08 & 24,51 & 25,22 & 23,21 & 18,04 & 7,18 & 14,46 & 11,40 & 8,55 & 11,81 & 12,88 & 12,33 \\
\hline $\mathrm{Nd}$ & 54,70 & 62,80 & 44,50 & 98,50 & 103,50 & 99,30 & 69,66 & 30,72 & 57,43 & 47,67 & 36,46 & 49,04 & 50,41 & 51,62 \\
\hline $\mathrm{Sm}$ & 10,10 & 11,50 & 9,20 & 19,60 & 20,30 & 19,40 & 12,02 & 6,76 & 11,65 & 10,20 & 8,15 & 10,70 & 9,17 & 11,23 \\
\hline $\mathrm{Eu}$ & 2,96 & 3,19 & 2,57 & 4,28 & 4,60 & 4,98 & 3,23 & 2,03 & 3,05 & 2,92 & 2,53 & 2,99 & 2,28 & 3,05 \\
\hline $\mathrm{Gd}$ & 8,92 & 10,31 & 9,33 & 17,46 & 18,95 & 18,09 & 9,05 & 6,68 & 11,05 & 10,11 & 8,22 & 10,65 & 7,35 & 10,89 \\
\hline $\mathrm{Tb}$ & 1,14 & 1,29 & 1,40 & 2,59 & 2,62 & 2,48 & 1,28 & 1,04 & 1,69 & 1,56 & 1,30 & 1,71 & 1,10 & 1,72 \\
\hline Dy & 6,26 & 6,89 & 7,63 & 14,59 & 14,68 & 13,93 & 6,73 & 5,89 & 9,45 & 8,75 & 7,29 & 9,61 & 6,04 & 9,59 \\
\hline Ho & 1,07 & 1,20 & 1,53 & 2,73 & 2,78 & 2,45 & 1,29 & 1,25 & 1,95 & 1,84 & 1,54 & 2,06 & 1,21 & 2,03 \\
\hline Er & 3,00 & 3,34 & 4,21 & 7,76 & 7,35 & 7,14 & 3,39 & 3,33 & 5,25 & 4,87 & 4,11 & 5,54 & 3,24 & 5,37 \\
\hline $\mathrm{Yb}$ & 2,60 & 2,80 & 3,90 & 6,90 & 6,20 & 6,10 & 2,92 & 3,05 & 4,79 & 4,47 & 3,77 & 5,23 & 2,93 & 4,89 \\
\hline $\mathrm{Lu}$ & 0,34 & 0,38 & 0,56 & 0,97 & 0,89 & 0,87 & 0,45 & 0,46 & 0,72 & 0,67 & 0,57 & 0,78 & 0,44 & 0,73 \\
\hline $\mathrm{Nb}_{\mathrm{N}} / \mathrm{Nb}^{*} \mathrm{~J}$ & 0,35 & 0,33 & 0,37 & 0,45 & 0,78 & 0,58 & 0,35 & 0,47 & 0,41 & 0,47 & 0,77 & 0,81 & 0,39 & 0,54 \\
\hline$\left(\mathrm{Ta}_{\mathrm{N}} / \mathrm{Ta}^{*}\right)$ & 0,44 & 0,36 & 0,38 & 0,41 & 0,63 & 0,57 & 0,46 & 0,54 & 0,43 & 0,50 & 0,87 & 0,93 & 0,46 & 0,65 \\
\hline$\left(\mathrm{Ti}_{\mathrm{N}} / \mathrm{Ti}^{*}\right)$ & 0,77 & 0,61 & 0,69 & 0,38 & 0,44 & 0,51 & 0,56 & 0,74 & 0,64 & 0,71 & 0,75 & 0,68 & 0,84 & 0,70 \\
\hline
\end{tabular}


Tabela 2. Composições químicas de elementos maiores, traços e terras raras de amostras representativas da Unidade Novo Gosto, no Domínio Canindé. Abreviação: P.F.= Perda ao fogo; n.d.= Não determinado.

Table 2. Chemical compositions of major, trace and rare earth elements of representative samples from Novo Gosto unit, Canindé Domain. Abbreviation: P.F.= Loss on ignition; $n . d .=$ not determined.

\begin{tabular}{|c|c|c|c|c|c|c|c|c|}
\hline & \multicolumn{8}{|c|}{ Unidade Novo Gosto } \\
\hline & CS-05A & CS-08 & CS-10A & CS-013 & CS-014 & CRN-88a & CRN-88b & CRN-272a \\
\hline $\mathrm{SiO}_{2}(\%)$ & 50,38 & 54,02 & 51,13 & 51,43 & 50,64 & 50,03 & 49,56 & 46,40 \\
\hline $\mathrm{TiO}_{2}$ & 3,09 & 2,65 & 2,00 & 1,01 & 1,19 & 2,94 & 2,52 & 2,16 \\
\hline $\mathrm{Al}_{2} \mathrm{O}_{2}$ & 12,29 & 13,44 & 16,19 & 13,97 & 14,37 & 14,12 & 15,16 & 15,28 \\
\hline $\mathrm{Fe}_{2} \mathrm{O}_{2}$ & 15,43 & 14,32 & 11,37 & 11,94 & 12,75 & 13,94 & 13,39 & 14,51 \\
\hline $\mathrm{MnO}$ & 0,31 & 0,25 & 0,19 & 0,23 & 0,22 & 0,24 & 0,22 & 0,21 \\
\hline $\mathrm{MgO}$ & 6,84 & 4,51 & 7,77 & 7,58 & 7,43 & 5,73 & 6,36 & 7,90 \\
\hline $\mathrm{CaO}$ & 9,07 & 7,77 & 9,61 & 13,34 & 10,98 & 8,55 & 7,90 & 8,24 \\
\hline $\mathrm{Na}_{2} \mathrm{O}$ & 1,69 & 2,39 & 2,91 & 0,99 & 2,68 & 3,65 & 3,73 & 3,57 \\
\hline $\mathrm{K}_{2} \mathrm{O}$ & 0,19 & 1,17 & 0,76 & 0,12 & 0,22 & 0,45 & 0,62 & 0,18 \\
\hline $\mathrm{P}_{2} \mathrm{O}_{5}$ & 0,28 & 0,49 & 0,49 & $<0,01$ & $<0,01$ & 0,35 & 0,29 & 0,24 \\
\hline $\mathrm{Cr}_{2} \mathrm{O}_{3}$ & 0,03 & $<0,01$ & 0,03 & 0,04 & 0,03 & n.d & n.d & n.d \\
\hline P.F. & 2,83 & 1,66 & 0,88 & 0,68 & 0,59 & 0,20 & 0,69 & 1,39 \\
\hline Total & 102,42 & 102,68 & 103,31 & 101,28 & 101,09 & 100,20 & 100,44 & 100,10 \\
\hline $\mathrm{Ba}(\mathrm{ppm})$ & 111 & 471 & 252 & 60 & 63 & 169 & 250 & 73 \\
\hline $\mathrm{Rb}$ & 5,70 & 26,10 & 14,70 & 0,90 & 5,60 & 5,30 & 11,80 & 5,31 \\
\hline $\mathrm{Sr}$ & 304 & 283 & 375 & 266 & 195 & 434 & 299 & 250 \\
\hline Th & 1,50 & 3,30 & 1,00 & 0,50 & 0,40 & 2,60 & 2,20 & 1,43 \\
\hline $\mathrm{U}$ & 0,43 & 1,00 & 0,44 & 0,15 & 0,13 & 0,77 & 2,00 & 0,38 \\
\hline $\mathrm{Zr}$ & 143 & 178 & 201 & 59 & 71 & 219 & 167 & 156 \\
\hline $\mathrm{Hf}$ & 4,14 & 5,30 & 5,06 & 1,51 & 1,63 & 5,41 & n.d & 3,93 \\
\hline $\mathrm{Nb}$ & 19,79 & 11,95 & 9,10 & 4,13 & 4,88 & 14,20 & 10,30 & 8,50 \\
\hline $\mathrm{Y}$ & 29,09 & 34,97 & 29,32 & 17,15 & 17,59 & 43,00 & 40,00 & 31,63 \\
\hline $\mathrm{Ta}$ & 1,11 & 0,76 & 0,46 & 0,23 & 0,22 & 0,99 & n.d & 0,55 \\
\hline $\mathrm{Cr}$ & n.d & n.d & n.d & n.d & n.d & 121 & 190 & 319 \\
\hline $\mathrm{Ni}$ & 64 & 24 & 119 & 127 & 115 & 42 & 62 & 47 \\
\hline V & 479 & 336 & 181 & 266 & 285 & 406 & 365 & 359 \\
\hline $\mathrm{La}$ & 17,10 & 24,00 & 22,40 & 6,90 & 5,30 & 18,90 & 6,00 & 11,70 \\
\hline $\mathrm{Ce}$ & 34,50 & 48,80 & 47,90 & 11,70 & 12,80 & 38,00 & 27,00 & 29,34 \\
\hline $\operatorname{Pr}$ & 4,55 & 6,42 & 6,34 & 1,72 & 1,95 & 6,72 & n.d & 4,04 \\
\hline $\mathrm{Nd}$ & 22,20 & 30,90 & 29,10 & 8,60 & 9,40 & 27,00 & 19,00 & 19,49 \\
\hline $\mathrm{Sm}$ & 5,80 & 7,60 & 6,60 & 2,40 & 2,70 & 7,87 & n.d & 5,35 \\
\hline $\mathrm{Eu}$ & 1,84 & 2,49 & 2,09 & 0,96 & 0,97 & 2,36 & n.d & 1,90 \\
\hline $\mathrm{Gd}$ & 6,52 & 8,60 & 7,26 & 2,99 & 3,16 & 8,25 & n.d & 6,00 \\
\hline $\mathrm{Tb}$ & 1,00 & 1,25 & 1,07 & 0,48 & 0,56 & 1,33 & n.d & 1,01 \\
\hline Dy & 6,45 & 7,79 & 6,46 & 3,27 & 3,50 & 7,41 & n.d & 5,78 \\
\hline Ho & 1,20 & 1,44 & 1,20 & 0,69 & 0,77 & 1,58 & n.d & 1,25 \\
\hline Er & 3,57 & 4,22 & 3,53 & 2,11 & 2,13 & 4,14 & n.d & 3,30 \\
\hline $\mathrm{Yb}$ & 3,20 & 3,70 & 3,10 & 1,80 & 2,00 & 3,55 & n.d & 2,97 \\
\hline $\mathrm{Lu}$ & 0,45 & 0,52 & 0,43 & 0,32 & 0,33 & 0,54 & n.d & 0,44 \\
\hline$\left(\mathrm{Nb}_{\mathrm{N}} / \mathrm{Nb}^{*}\right)$ & 1,28 & 0,44 & 0,56 & 0,71 & 1,08 & 0,67 & 0,81 & 0,69 \\
\hline$\left(\mathrm{Ta}_{\mathrm{N}} / \mathrm{Ta}^{*}\right)$ & 1,33 & 0,52 & 0,53 & 0,73 & 0,90 & 0,86 & n.d & 0,82 \\
\hline$\left(\mathrm{Ti}_{\mathrm{N}} / \mathrm{Ti}^{*}\right)$ & 1,39 & 0,92 & 0,82 & 0,91 & 0,99 & 1,02 & n.d & 0,95 \\
\hline
\end{tabular}

ocupam os campos do traquiandesito e de álcali -basalto, respectivamente (Fig. 7).

No diagrama AFM, que relaciona álcalis (Na20 + K20), ferro e magnésio (Irvine \& Baragar, 1971), as amostras de ortoanfibolitos ocupam o campo de composição não toleítica, com exceção de duas amostras (PLJ-022B e PLJ-022C), que estão posicionadas próximo ao limite da série toleítica (Fig. 8A). No entanto, no diagrama ternário de Jensen (1976), que relaciona $\left(\mathrm{FeO}+\mathrm{Fe}_{2} \mathrm{O}_{3}+\mathrm{TiO}_{2}\right)$ - $\mathrm{Al}_{2} \mathrm{O}_{3}$ - MgO, as amostras ocupam principalmente o campo de basaltos toleíticos alto-Fe, com apenas três amostras (CS-01, CS-03, CRN-31A) no campo de basaltos cálcio-alcalinos (Fig. 8B). A presença de quartzo e hiperstênio normativos na maioria das amostras, com exceção da amostra CRN-201, que apresenta hiperstênio e olivina normativos, corrobora com a afinidade toleítica das rochas e o 
caráter dominantemente supersaturado em sílica. A condição relativamente evoluída dessas rochas é sugerida pelos valores de $\mathrm{MgO}$ que variam de $2,54 \%$ a $7,29 \%$ e pelos teores de $\mathrm{SiO} 2$ de $48,3 \%$ a $57,19 \%$.

Para relacionar o comportamento dos elementos maiores e traço com a evolução do magmatismo, foram confeccionados diagramas binários utilizando-se o MgO como índice de diferenciação (Figs. 9 e 10). Nestes, observa-se que os teores de $\mathrm{SiO}_{2}, \mathrm{Na}_{2} \mathrm{O}, \mathrm{K}_{2} \mathrm{O}$ e $\mathrm{P}_{2} \mathrm{O}_{5}$ nas amostras da Unidade Gentileza aumentam à medida que o magma é fracionado, enquanto o $\mathrm{CaO}$ apresenta tendência ao empobrecimento, que é acompanhado, em parte, pelo $\mathrm{Al203}$, apesar da dispersão (Fig. 9). $\mathrm{O} \mathrm{FeO}_{\mathrm{t}}$ e o $\mathrm{TiO}_{2}$ apresentam-se dispersos em relação ao MgO, e podem refletir variações nos conteúdos de óxidos de Fe e Ti. Os padrões de enriquecimento e empobrecimentos em relação ao MgO são compatíveis com o fracionamento de olivina>clinopiroxênio>plagioclásio.

No estudo do comportamento dos elementos-traço (Fig. 10) foi possível observar que o Cr, que possui elevado coeficiente de partição em clinopiroxênio (Dostal et al., 1983), apresenta um padrão de enriquecimento associado ao empobrecimento de $\mathrm{MgO}$, enquanto o $\mathrm{Ni}$ apresenta empobrecimento. Estes padrões sugerem que, durante a evolução magmática das rochas, o fracionamento de olivina foi mais efetivo do que o de clinopiroxênio. Os demais elementos-traço apresentam um trend de enriquecimento associado ao empobrecimento do $\mathrm{MgO}$, sugerindo um padrão típico de elementos incompatíveis. $\mathrm{O}$ enriquecimento do $\mathrm{Sr}$

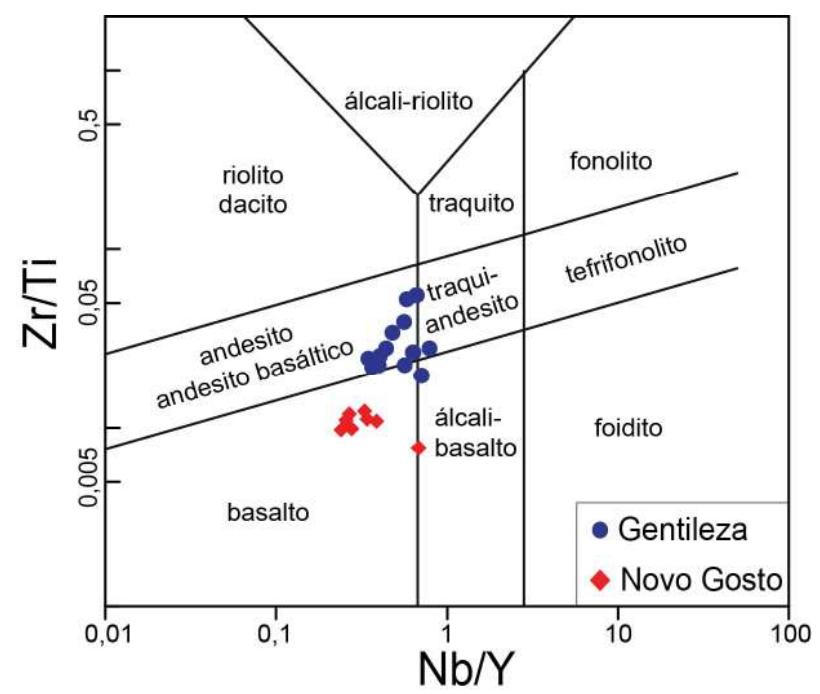

Figura 7. Diagrama de classificação Zr/Ti versus Nb/Y (Pearce, 1996) para os ortoanfibolitos das unidades Novo Gosto e Gentileza.

Figure 7. Zr/Ti versus Nb/Y plot (Pearce, 1996) to ortho-amphibolites from Novo Gosto and Gentileza units.

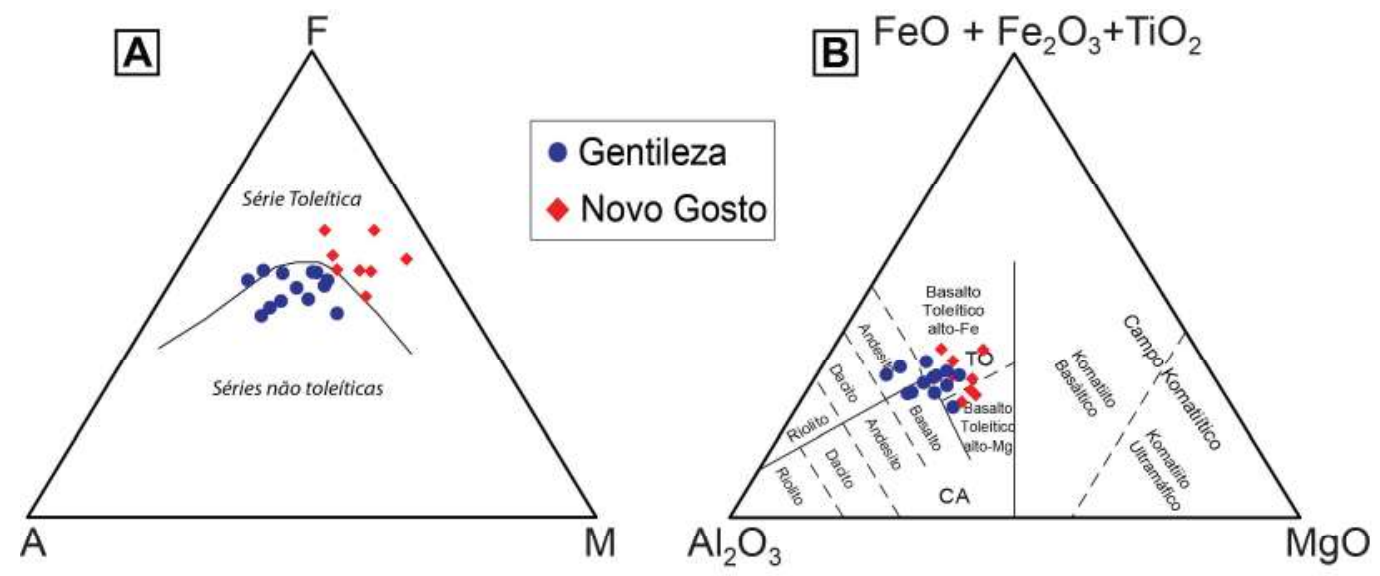

Figura 8. Classificação dos ortoanfibolitos das unidades Novo Gosto e Gentileza. A) Diagrama A $\left(\mathrm{Na}_{2} \mathrm{O}+\mathrm{K}_{2} \mathrm{O}\right)-\mathrm{F}(\mathrm{FeO})-\mathrm{M}(\mathrm{MgO})$ de Irvine e Baragar (1971); B) Diagrama de Jensen (1976).

Figure 8. Classification of ortho-amphibolites from Novo Gosto and Gentileza units. $\mathrm{A})\left(\mathrm{Na}_{2} \mathrm{O}+\mathrm{K}_{2} \mathrm{O}\right)-\mathrm{F}(\mathrm{FeO})-\mathrm{M}(\mathrm{MgO})$ diagram of Irvine and Baragar (1971); B) Jensen (1976) diagram. 
em relação ao $\mathrm{MgO}$, sugere que houve pouco fracionamento de plagioclásio, visto que este possui elevado coeficiente de partição para Sr (McKenzie \& O'Nions, 1991) (Fig. 10).

Os ETRs normalizados pelo Condrito C1 (McDonough \& Sun, 1995) (Fig. 11A) apresentamse com concentrações elevadas de ETRs leves (81379) e moderadas de ETRs pesados (18 - 51), que delineiam padrões geoquímicos marcados por moderados a elevados enriquecimentos em ETRs leves em relação aos ETRs pesados ( $\mathrm{LaN} / \mathrm{YbN}=4,32$ - 16,07). A leve anomalia negativa de $\mathrm{Eu}\left(\mathrm{Eu} / \mathrm{Eu}^{*}=\right.$ 0,69 a 0,93 ) sugere que houve pouco fracionamento de plagioclásio ao longo da evolução magmática.
No diagrama multi-elementar de elementos-traço normalizado para o manto primitivo (McDonough \& Sun, 1995) (Fig. 11B), as amostras da Unidade Gentileza apresentam um padrão de enriquecimento em elementos incompatíveis de Lu em direção ao Th, com destacadas anomalias negativas de Nb, Ta, Ti e P.

\subsubsection{Litoquímica da Unidade Novo Gosto}

Os resultados analíticos dos ortoanfibolitos da Unidade Novo Gosto são apresentados na tabela 2. 0 protólito dessas rochas, no diagrama $\mathrm{Nb} / \mathrm{Y}$ vs. Zr/Ti (Pearce, 1996), corresponde a ba-
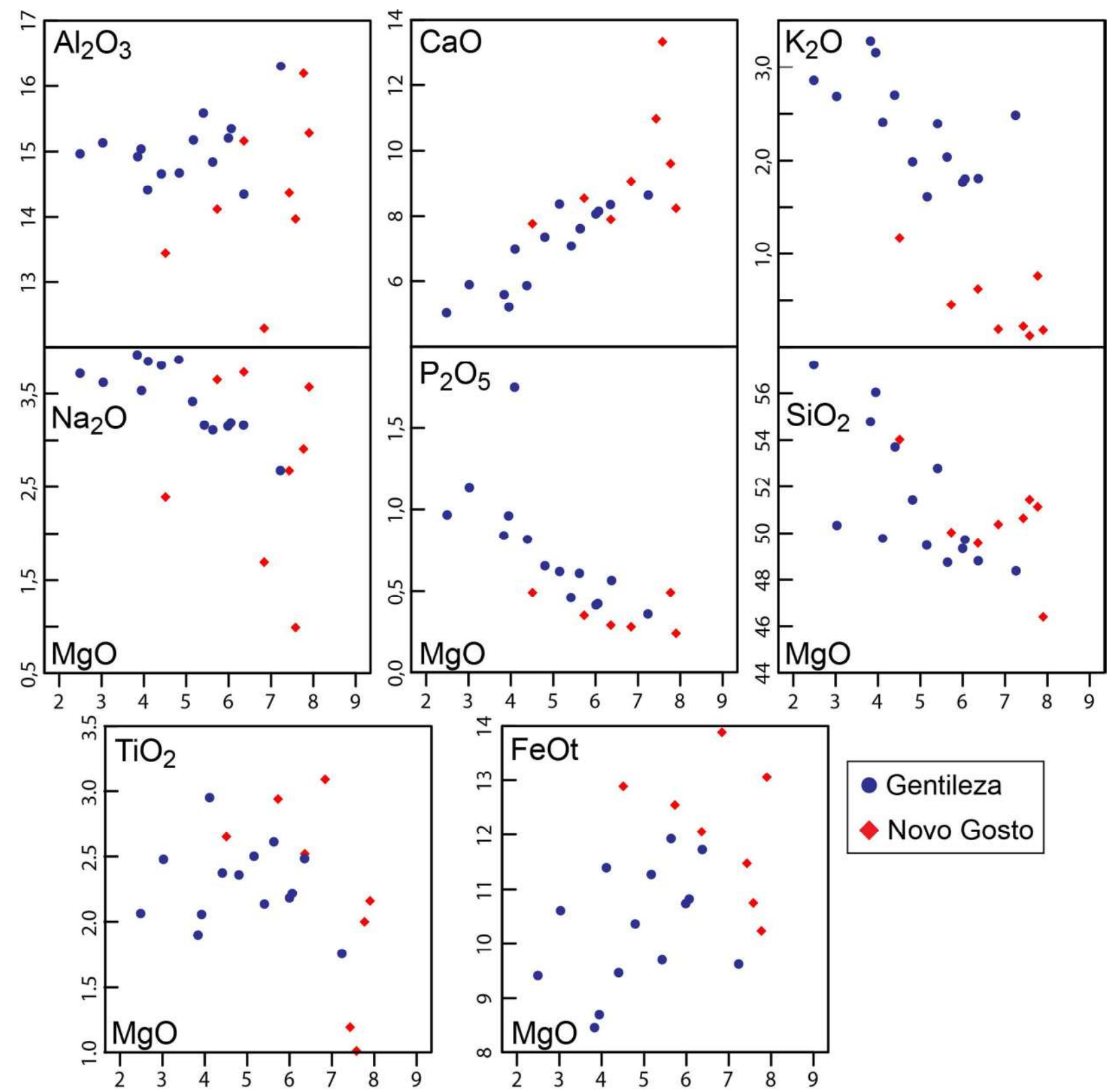

Figura 9. Diagramas binários de variação de elementos maiores versus MgO (em porcentagem de peso) para os ortoanfibolitos das unidades Novo Gosto e Gentileza.

Figure 9. Major elements versus MgO variation diagrams to ortho-amphibolites from Novo Gosto and Gentileza units. 
saltos subalcalinos, enquanto que no diagrama AFM (Irvine \& Baragar, 1971) enquadram-se na série toleítica (Figs. 7 e 8A). No diagrama ternário de Jensen (1976) as amostras ocupam o campo de basaltos toleíticos alto-Fe e alto-Mg (Fig. 8B). A afinidade toleítica dessas rochas é atestada pela presença, na maioria das amostras, de quartzo e hiperstênio normativos, que confere o caráter supersaturado em sílica, e de olivina e hiperstênio normativos na amostra CRN-272, que indica o caráter saturado em sílica. Estas rochas são levemente evoluídas, com 45,2 a $54 \%$ de $\mathrm{SiO}_{2}$ e 4,51 a $8,16 \%$ de MgO. A partir dos padrões de distribuição dos elementos maiores, menores e traços ver- sus o índice de diferenciação (MgO), identifica-se uma tendência de empobrecimento nos conteúdos de $\mathrm{CaO}$ e $\mathrm{Al}_{2} \mathrm{O}_{3}$ com o decréscimo dos conteúdos de $\mathrm{MgO}$, acompanhados pelo enriquecimento, de forma dispersa, dos conteúdos de $\mathrm{FeO}_{\mathrm{t}^{\prime}}, \mathrm{TiO}_{2}, \mathrm{SiO}_{2}, \mathrm{~K}_{2} \mathrm{O}$ e $\mathrm{Na}_{2} \mathrm{O}$ (Fig. 9). Estes padrões são comuns em sistemas evoluídos a partir de cristalização fracionada, envolvendo principalmente, o fracionamento de clinopiroxênio e plagioclásio. $\mathrm{O}_{2} \mathrm{O}_{5}$ apresenta uma leve correlação negativa com o MgO, sugerindo que não houve fracionamento efetivo de apatita no decorrer da evolução magmática. Os elementos Ni e Cr mostram uma redução dos teores com o declínio do MgO (Fig. 10), indicando o fracionamento
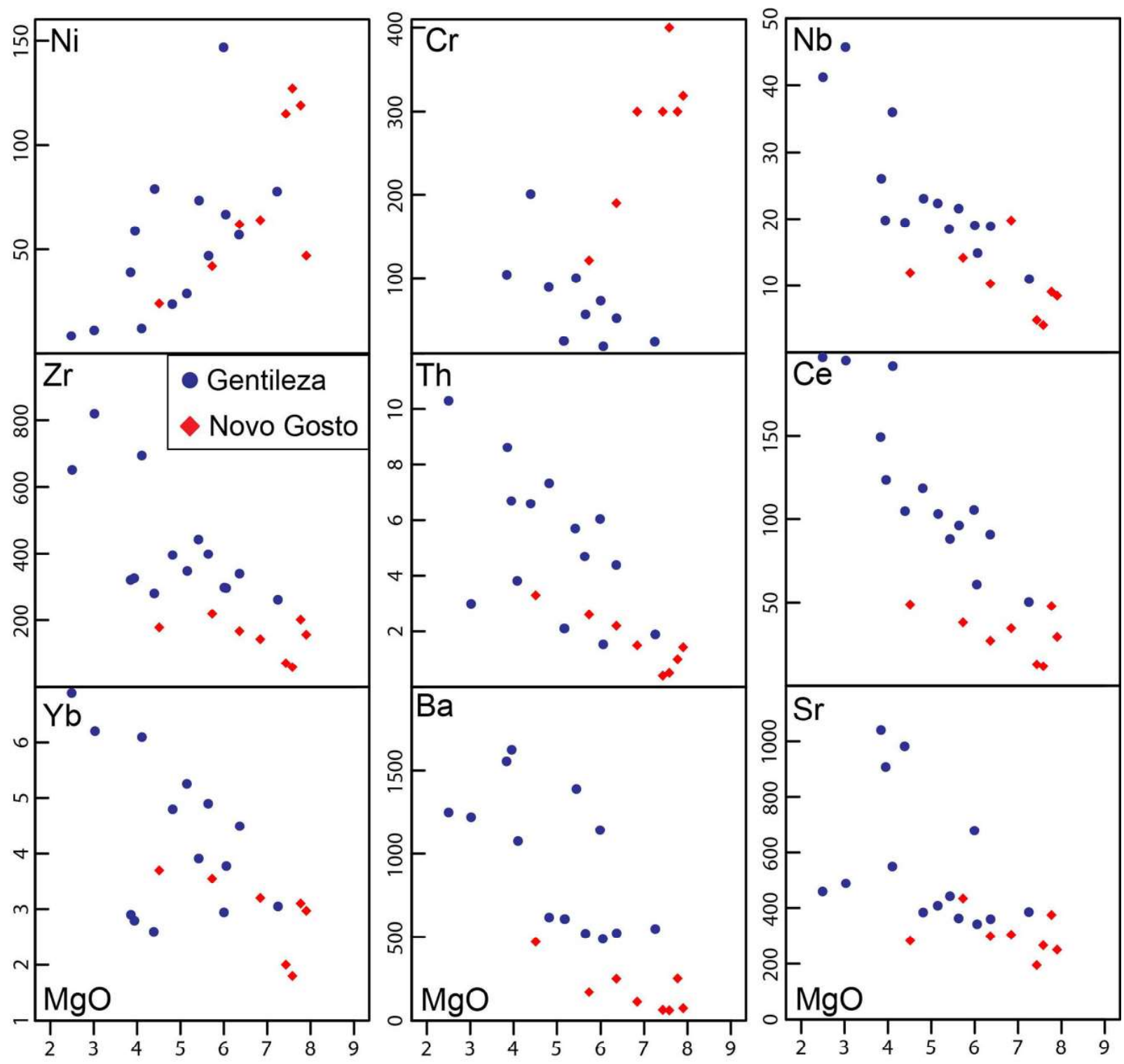

Figura 10. Diagramas de variação de elementos-traço (ppm) versus MgO (\%) para os ortoanfibolitos das unidades Novo Gosto e Gentileza.

Figure 10. Trace elements (ppm) versus $\mathrm{MgO}$ (wt\%) variation diagrams to ortho-amphibolites from Novo Gosto and Gentileza units. 
de olivina e clinopiroxênio. Os demais elementostraço e ETRs mostram um aumento dos teores com o decréscimo do $\mathrm{MgO}$, sugerindo um padrão típico de elementos incompatíveis.

Os padrões de ETRs das amostras da Unidade Novo Gosto normalizados pelo Condrito C1 (McDonough \& Sun, 1995) são apresentados na figura 11A. Esses padrões mostram moderadas concentrações de ETRs leves (19 - 101) e fracas de ETRs pesados $(11$ - 29) e relação ao condrito C1, que definem um padrão com fraco a moderado enriquecimento em ETRs leves em relação a ETRs pesados ( $\mathrm{LaN} / \mathrm{YbN}=1,8-4,91)$. Anomalias de $\mathrm{Eu}$ $\left(\mathrm{Eu} / \mathrm{Eu}^{*}=0,89-1,09\right)$ próximas da unidade sugerem que o fracionamento de plagioclásio não foi efetivo.

No diagrama de elementos-traço normalizado pelo manto primitivo (McDounough \& Sun, 1995), os elementos apresentam um padrão suave de empobrecimento do Th em direção ao Lu, exceto para moderadas anomalias negativas em $\mathrm{Nb}, \mathrm{Ta}, \mathrm{P}$ e Ti, presentes na maioria das amostras (Fig. 11B; Tab. 2). Observa-se que duas amostras

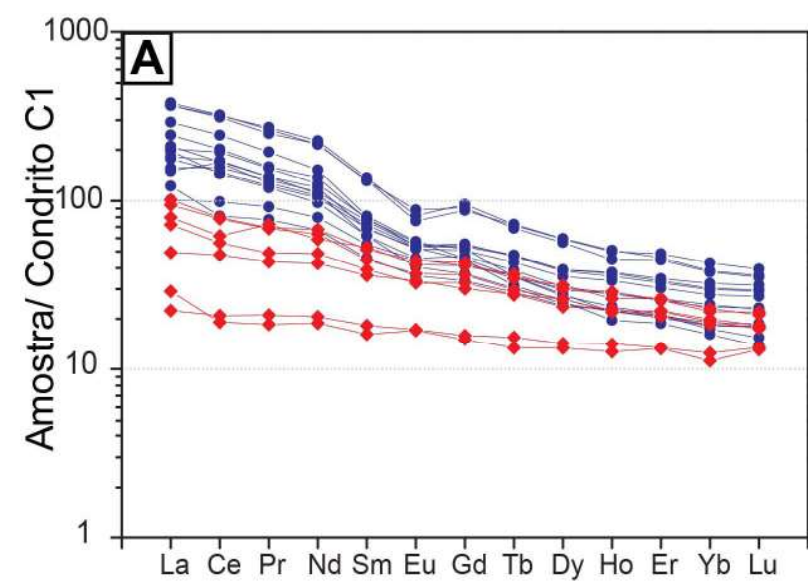

(CS-013 e CS-014) destoam do padrão geral das amostras desta unidade, apresentando padrões subhorizontalizados e empobrecidos em elementos-traço e ETRs quando comparadas com as demais amostras, além de forte anomalia negativa de P. Portanto, apesar do número reduzido de amostras, os dados geoquímicos dos ortoanfibolitos da Unidade Novo Gosto sugerem a existência de dois grupos de protólitos ígneos, que podem ser separados por características geoquímicas distintas: o primeiro grupo, denominado de alto-Ti, que prevalece na área estudada, caracterizado por conteúdos mais elevados de $\mathrm{TiO}_{2}(2,0 \%-3,0 \%)$ e $\mathrm{P}_{2} \mathrm{O}_{5}(0,2 \%$ a $0,5 \%$ ), que são acompanhados por maiores concentrações de HFSE ( $\mathrm{Zr}=132,0-219,0, \mathrm{Nb}=8,5$ $-19,8, \mathrm{Hf}=3,9-5,4$ e $\mathrm{Ta}=0,5-1,1)$ e $\sum$ ETR $(52,0$ - 147,8); o segundo grupo, denominado de baixo$\mathrm{Ti}$, ocorre somente no extremo oeste da área, e é caracterizado por baixos conteúdos de $\mathrm{TiO}_{2}(1,0 \%$ $-1,2 \%), \mathrm{P}_{2} \mathrm{O}_{5}<0,01 \%$, HFSE $(\mathrm{Zr}=59,0-71,0, \mathrm{Nb}=$ $4,1-4,9, \mathrm{Hf}=1,5-1,6$ e Ta$=\sim 0,2)$ e $\sum \operatorname{ETR}(43,9-$ $45,6)$.

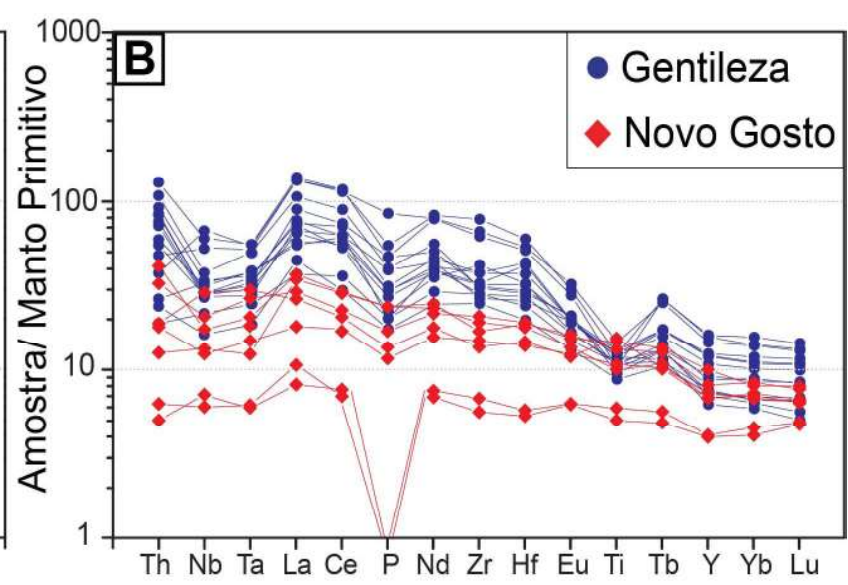

Figura 11. Padrões de abundância dos elementos terras raras e elementos-traço dos ortoanfibolitos das unidades Novo Gosto e Gentileza. A) Diagrama de elementos terras raras normalizados pelo Condrito C1; B) Diagrama multi-elementar de elementostraço normalizado pelo Manto Primitivo. Os padrões de normalização são de McDonough \& Sun (1995).

Figure 11. Abundance patterns of rare earth elements and trace elements to ortho-amphibolites from Novo Gosto and Gentileza units. A) Chondrite-normalized rare earth elements diagram; B) Primitive Mantle normalized multi-element diagram to ortho-amphibolites from Novo Gosto and Gentileza units. Normalization values are from McDonough \& Sun (1995).

\section{Discussão dos resultados}

\subsection{Interpretações petrográficas}

Os dados petrográficos evidenciam que as rochas máficas metamorfizadas da Unidade Gentileza tiveram uma história polimetamórfica similar às descritas para as rochas da Unidade Novo Gosto, com paragêneses metamórficas de Fácies Anfibo- lito marcadas por hornblenda \pm plagioclásio, com transformações para a Fácies Xisto Verde, marcadas principalmente por biotita \pm epídoto \pm clorita \pm sericita. A presença de minerais de baixo e médio grau metamórfico, observados nos ortoanfibolitos de ambas as unidades, sugerem que as rochas foram metamorfizadas no Fácies Anfibolito e sofreram processos retrometamórficos do Fácies Xisto Verde. 0 estudo mineralógico indica um provável 
envolvimento de hidrotermalismo, marcado principalmente pela presença de vênulas de calcita e epídoto. Esse processo, possivelmente, foi induzido pela entrada de corpos graníticos tardios e pela percolação de fluidos a partir de zonas de cisalhamento, mostrando-se intensos nas rochas da Unidade Novo Gosto.

\subsection{Relações petrogenéticas e suas implicações no} ambiente tectônico

Para entender os processos petrogenéticos e ambiente tectônico envolvidos na geração dos protólitos ígneos dos ortoanfibolitos das unidades Novo Gosto e Gentileza, foram comparadas as afinidades geoquímicas e teores de elementos químicos dessas unidades. Tendo em vista que trabalhos anteriormente desenvolvidos para as rochas dessas unidades sugeriram diferentes ambientes tectônicos, tais como tipo arco (Jardim de Sá et al., 1986; Trompette, 1994; Silva Filho, 1998) ou rifteamento continental (Oliveira \& Tarney, 1990; Bezerra, 1992; Seixas \& Moraes, 2000; Nascimento, 2005; Oliveira et al., 2010), foi escolhida uma sequência de diagramas discriminantórios que possibilita distinguir com maior segurança os dois ambientes, além de permitir o reconhecimento de assinaturas das fontes envolvidas. Por fim, foram efetuadas comparações dessas rochas, em diagrama multi-elementar, com basaltos de cordilheira meso-oceânica (N-MORB), basaltos de cordilheira meso-oceânica enriquecidos (E-MORB), basaltos de ilha oceânica (OIB) (Sun \& McDonough, 1989) e rochas de ambientes de rifte continental (Peate \& Hawkesworth, 1996; Mincato, 2000; Rocha-Júnior et al., 2013; ) e de arco de ilha (Chandrasekharam et al., 2009).

Na comparação dos dados químicos, observa-se que os ortoanfibolitos da Unidade Gentileza são mais diferenciados que os da Unidade Novo Gosto, com composições equivalentes a andesitos e andesitos basálticos de afinidade toleítica, com tendência à cálcio-alcalina, enquanto as rochas da Unidade Novo Gosto correspondem a basaltos toleíticos (Fig. 7). Ambas as unidades possuem distribuição da maioria dos elementos maiores e traço, frente aos valores do índice de diferenciação, sugestivos de evolução por cristalização fracionada.
Apesar das semelhanças, os ortoanfibolitos da Unidade Gentileza são em média 1,5 a 3 vezes mais enriquecidos em LILE, HFSE e ETRs que os valores dos ortoanfibolitos da Unidade Novo Gosto, com exceção do Ti, cujos teores são semelhantes aos do grupo alto-Ti da Unidade Novo Gosto. Estas características geoquímicas foram observadas por Oliveira \& Tarney (1990), que sugeriram derivações de fontes distintas do manto para os magmas que geraram os protólitos ígneos dessas unidades. No entanto, ambas as unidades apresentam algumas características geoquímicas semelhantes, como é o caso das assinaturas com anomalias negativas de $\mathrm{Nb}$, Ta, Ti e $\mathrm{P}$, e padrões de enriquecimento de ETRL em relação aos ETRP (Figs. 11A-B). Anomalias negativas de Nb, Ta e Ti são características de basaltos de arcos vulcânicos, geradas a partir do fracionamento destes elementos em relação aos elementos Th e ETRL, durante a desidratação e fusão parcial da crosta subductada, sendo o Th e os ETRL transferidos desta para a cunha do manto, enquanto que o $\mathrm{Nb}$, Ta e Ti não são transferidos às fases fluídas, ficando insolúveis e retidos na placa subductada (Wilson, 1989; Pearce, 1996; Condie, 2001). Todavia, anomalias negativas de $\mathrm{Nb}$, Ta e Ti são também observadas em basaltos continentais, denominados de basaltos continentais semelhantes a arco (arc-like continental basalts). A origem desses basaltos tem sido atribuída a fusões parciais de manto litosférico subcontinental (SCLM) modificado por subducção prévia (Hawkesworth et al., 1995; Li et al., 2008; Wang et al., 2014), à contaminação de magmas derivados da astenosfera por componentes litosféricos (Xia, 2014) ou pela fusão parcial de SCLM modificado por fluidos gerados da desidratação da zona de transição do manto, entre 410 e 660 km de profundidade (Wang et al., 2015, 2016).

$\mathrm{Na}$ determinação do ambiente tectônico em que foram gerados os protólitos dos ortoanfibolitos das unidades Novo Gosto e Gentileza, os dados geoquímicos dos litotipos estudados foram inicialmente plotados no diagrama Zr vs. Zr/Y (Pearce \& Norry, 1979) (Fig. 12A). Neste diagrama, as rochas ocupam principalmente o campo de basaltos intraplaca (WPB), devido aos altos teores e razões de Zr e Zr/Y, respectivamente. Da mesma forma, quando plotadas no diagrama Zr vs. Ti (Pearce, 
1996), devido aos altos valores de $\mathrm{Zr}$ e Ti, as amostras, em sua maioria, ocupam o campo de basaltos intraplaca, com exceção das duas amostras da Unidade Novo Gosto (CS-013 e CS-014), que possuem baixos teores de Ti e plotam no campo de basaltos de arco vulcânico (VAB) (Fig. 12B).

No diagrama ternário V-Ti-Sm (Vermeesch, 2006), os ortoanfibolitos das unidades Novo Gosto e Gentileza ocupam os campos de MORB e OIB, respectivamente (Fig. 13A). Este diagrama apresenta grande eficiência em separar rochas básicas de ambiente intraplaca derivadas de fontes mais empobrecidas, similares ao MORB, ou enriquecidas, similares a OIB, daquelas relacionadas com ambientes tipo arco. Os resultados observados no diagrama são compatíveis com a hipótese de geração dos protólitos ígneos em ambiente intraplaca, envolvendo a participação de duas fontes mantélicas, uma mais empobrecida para os protólitos ígneos da Unidade Novo Gosto e outra mais enriquecida, para os protólitos ígneos da Unidade Gentileza.

Recentemente, Wang et al. (2016) propuseram um diagrama ternário baseado em razões de elementos-traço, Ti/V, Zr/Sm e Sr/Nd, para distinguir basaltos de ambiente de arco dos basaltos continentais similares a arco (Fig. 13B). Neste, os basaltos continentais definem um trend ao longo do limite Ti/V - Zr/Sm, enquanto os basaltos de arco definem um trend marcado pelo enriquecimento em Sr, que é quase perpendicular ao trend dos basaltos continentais. Neste diagrama, obser- va-se claramente que as amostras das unidades estudadas formam um trend típico de basaltos continentais.

Com o objetivo de identificar as possíveis fontes envolvidas na geração dos protólitos dos ortoanfibolitos, bem como distinguir os efeitos da contaminação crustal daqueles que possuem assinaturas de subducção, utilizou-se o diagrama binário Nb/Yb vs. Th/Yb de Pearce (2008) (Fig. 14A). A razão $\mathrm{Nb} / \mathrm{Yb}$ varia em função dos diferentes tipos de fonte e de graus de fusão, enquanto a razão Th/ Yb é sensível aos efeitos de contaminação crustal e aos componentes de subducção, apesar de variar em função da fonte (Pearce, 2008). Conforme o autor deste diagrama, basaltos intraplaca derivados de pluma mantélica e MORB, sem relações com zonas de subducção e contaminação crustal, posicionam-se dentro do campo MORB-OIB do diagrama, enquanto que rochas relacionadas a zonas de subducção e contaminação crustal, posicionam-se, de forma oblíqua e subparalela, fora deste campo (Pearce, 2008). Neste diagrama, duas amostras da Unidade Novo Gosto e quatro amostras da Unidade Gentileza plotaram no campo MORB-OIB, próximas ao E-MORB, enquanto as demais amostras posicionaram-se fora deste campo, formando um trend subparalelo em direção ao OIB, adentrando no campo de arco continental. 0 posicionamento das amostras dentro do campo MORB-OIB sugere o envolvimento de uma fonte enriquecida, tipo EMORB, na geração dos protólitos das duas unidades, enquanto que as amostras posicionadas fora
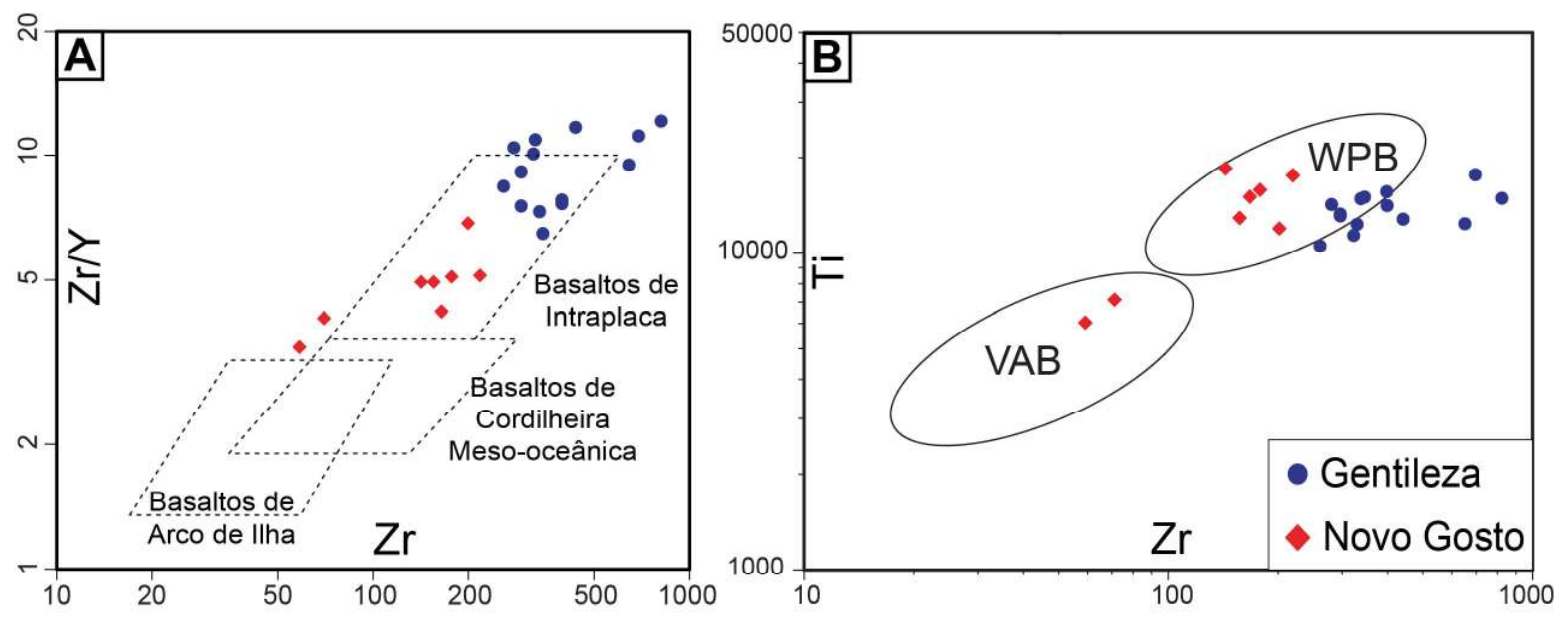

Figura 12. Diagramas de discriminação tectônica aplicados às rochas ortoanfibolíticas das Unidades Novo Gosto e Gentileza. A) Zr versus Z/Y (Pearce \& Norry, 1979); B) Ti versus Zr (Pearce, 1996). Abreviações: VAB- Basalto de arco vulcânico; WPBbasalto intraplaca.

Figure 12. Tectonic discriminant diagrams applied to ortho-amphibolitic rocks of Novo Gosto and Gentileza units. A) Zr versus Z/ Y (Pearce and Norry, 1979); B) Ti versus Zr (Pearce, 1996). Abbreviations: VAB- Basalt Volcanic Arc; WPB- Within Plate Basalts. 
do campo MORB-OIB, formam um trend semelhante ao atribuído por Pearce (2008) como resultado de contaminação crustal ou reciclagem profunda. No diagrama discriminante $\mathrm{NbN}$ vs. ThN (normalizado pelo N-MORB de Sun \& McDonough, 1989) de Saccani (2015) (Fig. 14B), a maior parte das amostras posicionam-se no campo de ambientes tipo rifte ou não relacionados com subducção. As amostras que plotam no ambiente de arco continental são influenciadas pelo enriquecimento em Th e distribuem-se em um trend semelhante ao indicado para assimilação crustal, concomitante com cristalização fracionada (AFC). Neste diagrama, observa-se que as amostras baixo-Ti da Unidade Novo Gosto posicionam-se após o N-MORB, próximo do E-MORB, enquanto as demais amostras dessa unidade encontram-se entre E-MORB e OIB. As amostras da Unidade Gentileza mostram uma forte participação de componentes tipo OIB, o que justifica os padrões de enriquecimento observados em outros diagramas. Estas constatações, apesar de não serem conclusivas, reforçam a hipótese da atuação de diferentes fontes na geração dos protólitos ígneos das duas unidades e que contaminações por assimilação crustal e/ou metassomatismo por subducção prévia podem ter ocorrido.

A comparação dos padrões de elementostraço e terras raras das rochas estudadas com os padrões de fontes tipo OIB, N-MORB e E-MORB (Sun \& McDonough, 1989) e contaminantes, representados por crosta continental superior e inferior (Rudnick \& Gao, 2003) (Fig. 15A), reforça as cons- tatações obtidas nos diagramas de discriminação tectônica e evidencia padrões de enriquecimento crescentes. Estes padrões partem dos ortoanfibolitos baixo-Ti da Unidade Novo Gosto, que possui um padrão semelhante ao E-MORB, passando aos ortoanfibolitos alto-Ti desta unidade, com padrão intermediário entre E-MORB e OIB, culminando nos ortoanfibolitos da Unidade Gentileza, que apresenta um padrão semelhante ao OIB. No entanto, como constatado anteriormente, as anomalias negativas de $\mathrm{Nb}, \mathrm{Ta}$, Ti e $\mathrm{P}$ presentes na maior parte das amostras não são características de padrões E-MORB e OIB, mas se assemelham aos padrões de crosta superior e inferior (Fig. 15A).

As características citadas acima são também observadas em rochas básicas relacionadas à ambientes de arco e rifte intracontinental, como observado no diagrama multi-elementar da Figura 15B. Neste, é possível notar a similaridade dos padrões das rochas das unidades Novo Gosto (alto-Ti) e Gentileza com os de rochas básicas da Formação Serra Geral, conforme Oliveira \& Tarney (1990) destacaram. No entanto, o padrão das rochas baixo-Ti da Unidade Novo Gosto é mais empobrecido, não possui semelhança com os das rochas básicas da Formação Serra Geral, nem com os basaltos do Arco de Sunda (Chandrasekharam et al., 2009), exceto para a proeminente anomalia negativa de $\mathrm{Nb}$ e Ta observadas nestas rochas. A presença de rochas básicas com teores contrastantes de Ti (baixo e alto-Ti) é descrita em diversos derrames basálticos continentais, como por exemplo: Grande Pro-

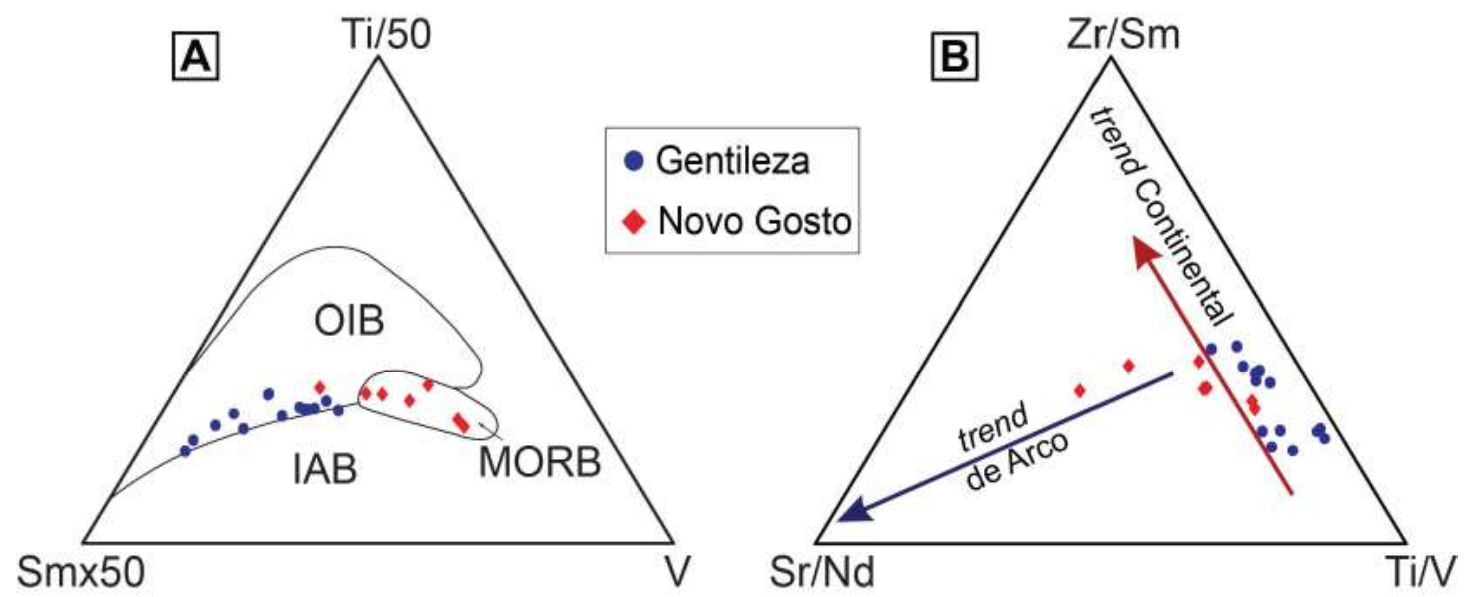

Figura 13. Diagramas ternários de discriminação tectônica aplicados às rochas ortoanfibolíticas das unidades Novo Gosto e Gentileza. A) V-Ti-Sm (Vermeesh, 2006); B) Ti/V- Zr/Sm-Sr/Nd (Wang et al., 2016). Abreviações: MORB - basaltos de cordilheira meso-oceânica; OIB - basaltos de ilha oceânica; IAB- basaltos de arco de ilha.

Figure 13. Ternary tectonic discrimination diagrams to ortho-amphibolitic rocks of Novo Gosto and Gentileza units. A) V-Ti-Sm plot (Vermeesh, 2006); B) Ti/V-Zr/Sm-Sr/Nd plot (Wang et al., 2016). Abbreviations: MORB- mid-ocean ridge basalts; OIB-ocean island basalts; IAB- island arc basalts. 

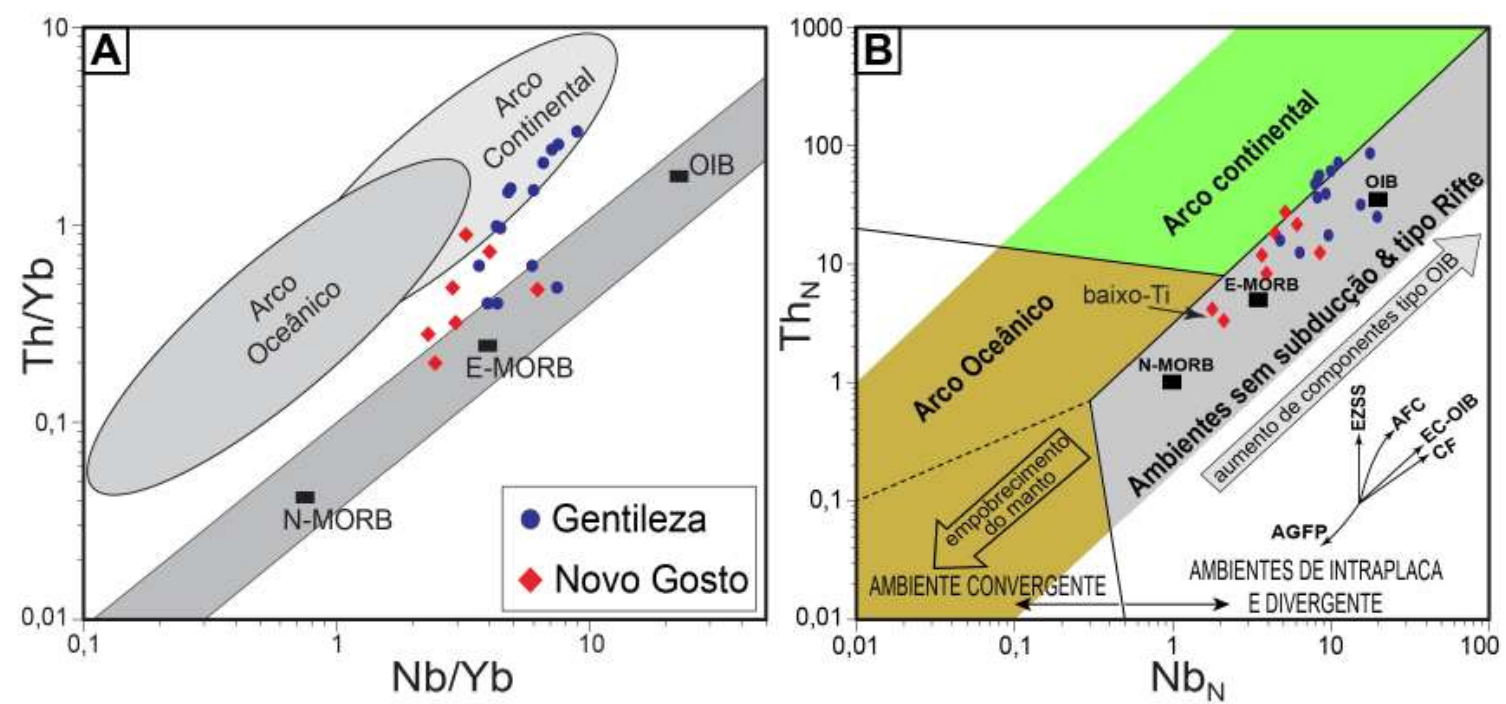

Figura 14. Diagramas de discriminação tectônica aplicados às rochas ortoanfibolíticas das unidades Novo Gosto e Gentileza. A) Nb/Yb vs. Th/Yb (Pearce, 2008); B) NbN vs. ThN (Saccani, 2015). Os elementos estão normalizados pelo N-MORB (Sun \& McDonough, 1989). Abreviações: N-MORB - basaltos de cordilheira meso-oceânica; E-MORB - basaltos de cordilheira meso-oceânica enriquecidos; OIB - basaltos de ilhas oceânicas; AGFP - aumento de grau de fusão parcial; EZSS - enriquecimento de zona de suprasubducção; AFC - assimilação concomitante com cristalização fracionada; EC-OIB - enriquecimento em componentes tipo OIB; CF - cristalização fracionada.

Figure 14. Tectonic discriminant diagrams applied to ortho-amphibolites rocks of Novo Gosto and Gentileza units. A) Nb / Yb vs. Th / Yb (Pearce, 2008); B) NbN vs. ThN (Saccani, 2015). The elements have normalized by N-MORB (Sun \& McDonough, 1989). Abbreviations: $N$-MORB - normal mid-ocean ridge basalts; E-MORB- enriched mid-oceanic ridge basalts; OIB-ocean island basalts; AGFP - increasing partial melting degree; EZSS - supra-subduction zone enrichment; AFC - assimilation-fractional crystallization; EC-OIB: ocean island-type (plume-type) component enrichment; $C F$ - fractional crystallization.

víncia Ígnea do Karoo (Jourdan et al., 2007), Grande Província Ígnea dos Traps Siberianos (Ivanov et al., 2008), Formação Serra Geral - Província Ígnea do Paraná (Peate \& Hawkesworth, 1996), Derrames Basálticos Continentais do Deccan (Melluso et al., 2004), entre outros. Nestas, os basaltos baixo-Ti apresentam assinaturas de subducção semelhantes às descritas nas rochas estudadas e são interpretadas como produtos de fusões parciais de SCLM modificado por subducção prévia (Jourdan et al., 2007; Li et al., 2008) ou produtos de fusões parciais de SCLM modificado por fluidos, gerados pela desidratação da zona de transição do manto (Wang et al., 2015, 2016).

Ao comparar, em maior detalhe, os padrões de elementos incompatíveis das rochas estudadas com os das rochas básicas da Formação Serra Geral (Fig. 15B), observa-se que os ortoanfibolitos alto-Ti da Unidade Novo Gosto apresentam teores de elementos-traço semelhantes às das rochas básicas alto-Ti do tipo Paranapanema (Rocha-Júnior et al., 2013), enquanto os ortoanfibolitos da Unidade Gentileza apresentam teores dominantemente mais enriquecidos que estes, principalmente em $\mathrm{Zr}$ e Hf, e se assemelham mais ao tipo Urubici (Mincato, 2000), porém não tão enriquecidos em
Ti. Rocha-Júnior et al. (2013) sugerem que os basaltos alto-Ti da Formação Serra Geral foram originados de SCLM metassomatizado e enriquecido por fluídos e/ou magmas relacionados com processos de subducção do Neoproterozoico. Modelos petrogenéticos envolvendo contaminação crustal são somente assumidos para os basaltos baixo-Ti da Formação Serra Geral, que podem ter envolvido a assimilação de componentes crustais do Paleoproterozoico e Neoproterozoico (Barreto et al., 2016).

Um modelo petrogenético semelhante ao sugerido por Rocha-Júnior et al. (2013), para explicar a formação dos basaltos alto-Ti da Formação Serra Geral, pode ser assumido para explicar a geração dos protólitos ígneos das Unidades Novo Gosto e Gentileza. No entanto, neste caso, diversos fatores sugerem o envolvimento de assimilação de crosta na geração dessas rochas. Materiais crustais são caracterizados por baixas razões de $\mathrm{Nb} /$ $\mathrm{La}, \mathrm{Sm} / \mathrm{Nd}$, além de baixos teores de $\mathrm{Mg}$ e altos teores de SiO2, acompanhados por valores de $\varepsilon N d(t)$ negativos (e.g. Taylor \& McLennan, 1985; Condie, 1993; Condie \& Selverstone, 1999; Rudnick \& Gao, 2003). Diferente dessas, as rochas básicas derivadas do manto astenosférico possuem $\mathrm{Nb} / \mathrm{La}>1$, 
$\mathrm{Sm} / \mathrm{Nd}$, além de altos teores de $\mathrm{Mg}$, baixos teores de $\mathrm{SiO} 2$ e valores de $\mathrm{ENd}(\mathrm{t})$ positivo. Os ortoanfibolitos da Unidade Gentileza apresentam $\mathrm{Nb} / \mathrm{La}<1 \mathrm{e}$ baixas razões de $\mathrm{Sm} / \mathrm{Nd}$, semelhantes às observadas em crosta continental superior e inferior (Tab. 3), além de apresentar correlações negativas entre La/Sm - Nb/La (Fig. 16A). Nos ortoanfibolitos da Unidade Novo Gosto, as razões de $\mathrm{Nb} / \mathrm{La}$ e $\mathrm{Sm} / \mathrm{Nd}$ são bastante variáveis, com proporções de crosta superior até OIB (Tab.3), que são acompanhadas por correlações negativas entre $\mathrm{La} / \mathrm{Sm}$ - $\mathrm{Nb} / \mathrm{La}$ (Fig. 16B). Razões $\mathrm{Nb} / \mathrm{La}$ e $\mathrm{Sm} / \mathrm{Nd}$ próximas às observadas na crosta continental superior, acompanhadas por correlações negativas entre $\mathrm{La} / \mathrm{Sm}$ - Nb/La, são indicativas da presença de contaminação crustal durante a formação dos protólitos ígneos das unidades Novo Gosto e Gentileza. Argumentos semelhantes a estes foram utilizados por Wang et al. (2016), para identificar a participação de contaminação crustal nos Derrames Basálticos Continentais do Deccan.

Dados de $\varepsilon N d(t)$ negativos obtidos por Nascimento (2005) para as rochas da Unidade Gentileza e levemente positivos para a Unidade
Novo Gosto (Tab. 4) corroboram com a hipótese da participação de diferentes graus de contaminação crustal durante a formação dos protólitos das rochas estudadas. Na tabela 4 são apresentados dados de amostras selecionadas em que é possível observar uma evidente correlação positiva entre as razões $\mathrm{Nb} / \mathrm{La}, \mathrm{Nb} / \mathrm{Th}, \mathrm{Sm} / \mathrm{Nd}$ e $\varepsilon N d(\mathrm{t})$, e uma correlação negativa destas com $(\mathrm{La} / \mathrm{Yb}) \mathrm{N}$, que indicam diferentes graus de assimilação na formação dessas rochas. Vale lembrar que Nascimento et al. (2017) identificaram rochas híbridas na Unidade Gentileza, formadas por misturas de rochas máficas e metasienogranitos de afinidade alcalina. Da mesma forma, nos ortoanfibolitos da Unidade Novo Gosto foi também observado, em campo, interações destas rochas com rochas metasienograníticas. Estas evidências de interações entre os protólitos ígneos dos anfibolitos das unidades Novo Gosto e Gentileza com rochas félsicas podem explicar, em parte, as assinaturas de contaminação crustal evidenciadas na geoquímica das rochas estudadas. No entanto, são necessários estudos envolvendo geoquímica isotópica para validar essa hipótese.
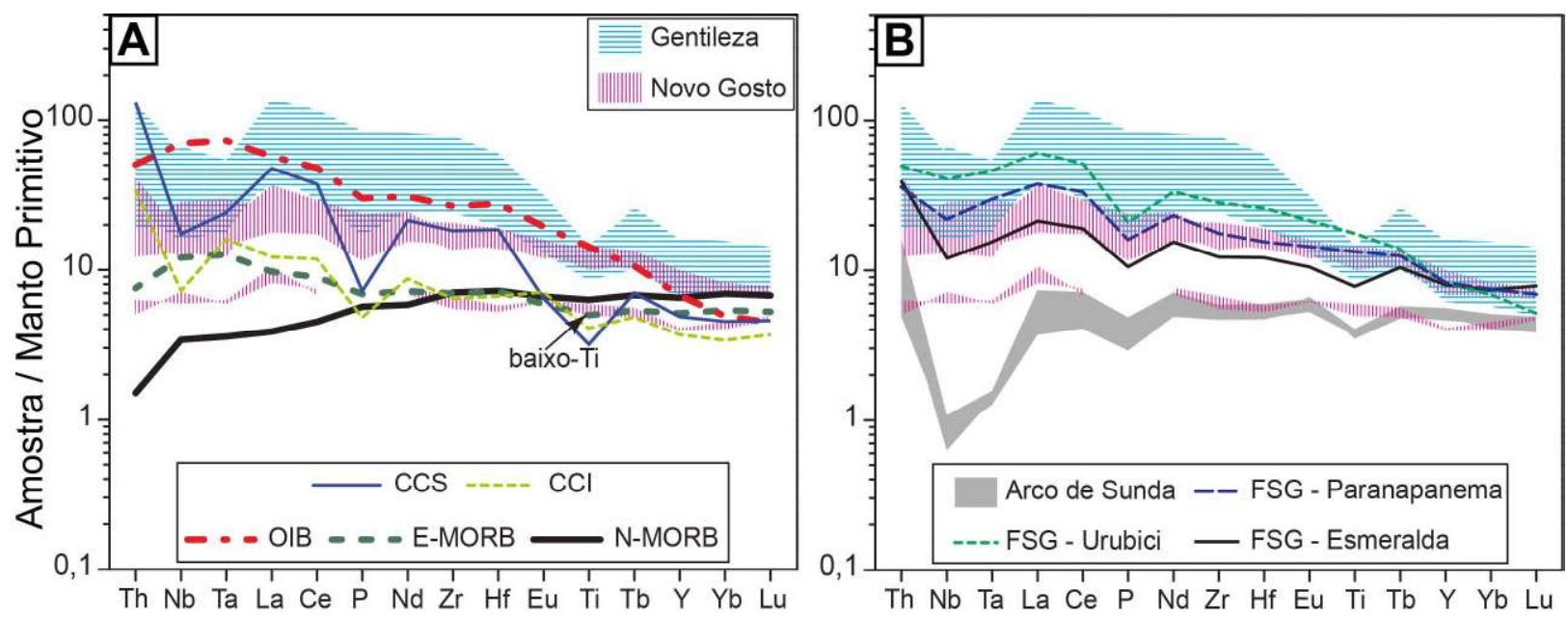

Figura 15. Diagramas multi-elementares normalizados pelo manto primitivo (McDonough \& Sun, 1995) dos ortoanfibolitos das unidades Novo Gosto e Gentileza comparados com: A) N-MORB, E-MORB, OIB (Sun \& McDonough, 1989), CCS (crosta continental superior) e CCI (crosta continental inferior) (Rudnick \& Gao, 2003); B) Rochas básicas de rifte continental da Formação Serra Geral (FSG), representada por basaltos e basaltos andesíticos alto-Ti tipo Urubici (Mincato, 2000) e Paranapanema (Rocha-Júnior et al., 2013) e basaltos baixo-Ti tipo Esmeralda (Peate \& Hawkesworth, 1996), e basaltos do Arco de Ilha do Arco de Sunda (Chandrasekharam et al., 2009).

Figure 15. Primitive mantle (McDonough \& Sun, 1995) normalized multi-element diagram of ortho-amphibolites from Novo Gosto and Gentileza units, compared to samples from: A) N-MORB, E-MORB, OIB (Sun \& McDonough, 1989), CCS (upper continental crust) and CCI (lower continental crust) (Rudnick \& Gao, 2003); B) Basic rocks from Serra Geral Formation (FSG), represented by basalts and andesitic basalts high-Ti fromUrubici (Mincato, 2000) and Paranapanema types (Rocha-Júnior et al., 2013) and low-Ti basalts Esmeralda-type (Peate, 1996), and island arc basalts from Sunda Arc (Chandrasekharam et al., 2009). 
Tabela 3. Razões Nb/La e Sm/Nd dos ortoanfibolitos das unidades Novo Gosto e Gentileza, N-MORB, OIB, E-MORB, CCS e CCI. Fontes: N-MORB, E-MORB e OIB (Sun \& McDonough, 1989); Crosta Continental Superior (CCS) e Crosta Continental Inferior (CCI) (Rudnick \& Gao, 2003)

Table 3. Nb/La and Sm/Nd ratios for ortho-amphibolites from Novo Gosto and Gentileza units, N-MORB, OIB, E-MORB, CCS and CCI. Sources: N-MORB, E-MORB and OIB (Sun \& McDonough, 1989); Upper Continental Crust (CCS) and Lower Continental Crust (CCI) (Rudnick \& Gao, 2003)

\begin{tabular}{lcc}
\hline & Nb/La & Sm/Nd \\
\hline Gentileza & $0,34-0,63$ & $0,17-0,22$ \\
Novo Gosto alto-Ti & $0,41-1,72$ & $0,23-0,29$ \\
Novo Gosto baixo-Ti & $0,60-0,92$ & $0,28-0,29$ \\
N-MORB & 0,93 & 0,36 \\
E-MORB & 1,32 & 0,29 \\
OIB & 1,3 & 0,26 \\
CCS & 0,39 & 0,17 \\
CCI & 0,63 & 0,25 \\
\hline
\end{tabular}


Figura 16. Razões La/Sm vs. Nb/La para os ortoanfibolitos das unidades Gentileza (A) e Novo Gosto (B). Figure 16. La/Sm vs. Nb/La ratios to ortho-amphibolites of Gentileza (A) and Novo Gosto units (B).

Tabela 4. Comparação de razões de elementos-traço, ETRs e ETRs normalizados pelo Condrito CI (McDonough e Sun, 1995) e dados isotópicos de $\mathrm{ENd}(\mathrm{t})$ dos ortoanfibolitos das unidades Novo Gosto e Gentileza. Os dados das amostras iniciadas pela sigla CRN foram obtidos de Nascimento (2005). Abreviação: n.d. = não determinado.

Table 4. Comparison among trace elements, REE and REE ratios normalized by Condrito CI (McDonough and Sun, 1995) and ENd (t) of ortho-amphibolites of Novo Gosto and Gentileza units. Data obtained from Nascimento (2005). Data of CRN abbreviation samples have obtained from Nascimento (2005). Abbreviation: n.d.= not determined.

\begin{tabular}{ccccccc}
\hline Unidade & Amostra & Nb/La & Sm/Nd & Nb/Th & (La/Yb)N & $\mathbf{E N d}_{(\mathbf{T})}$ \\
\hline \multirow{3}{*}{ Gentileza } & CRN-251b & 0,62 & 0,22 & 9,87 & 4,32 & $-0,67$ \\
& CRN-254 & 0,44 & 0,18 & 3,17 & 10,07 & $-3,9$ \\
& CRN-31a & 0,37 & 0,17 & 3,01 & 16,1 & $-9,18$ \\
\hline \multirow{3}{*}{ Novo Gosto } & CS-05A & 1,16 & 0,26 & 13,19 & 1,85 & n.d. \\
& CRN-272a & 0,73 & 0,27 & 5,94 & 2,68 & 0,82 \\
& CS-08 & 0,5 & 0,25 & 3,62 & 4,41 & n.d. \\
\hline
\end{tabular}

\section{Conclusões}

Os ortoanfibolitos da Unidade Novo Gosto ocorrem como diques intrusivos em sienogranitos e intercalados com metassedimentos, onde não é possível assumir, devido aos processos metamór- ficos e deformacionais, se originalmente constituíam rochas efusivas ou enxames de rochas intrusivas do tipo soleira.

Os ortoanfibolitos da Unidade Gentileza ocorrem na forma de corpos hipabissais, onde a filiação ígnea dos anfibolitos é clara e destacada pe- 
las feições reliquiares de misturas tipo mingling e mixing, evidenciadas por interações entre termos máficos (anfibolitos) e termos félsicos, representados por metasienogranitos de afinidade alcalina.

Os dados petrográficos indicam que os protólitos ígneos das duas unidades foram metamorfizados em condições de Fácies Anfibolito e sofreram transformações retrometamórficas para o Fácies Xisto Verde. Evidências de processos hidrotermais também estão impressas nas rochas e devem estar relacionados à entrada de corpos graníticos tardios e zonas de cisalhamento.

Os dados químicos indicam que os protólitos dos ortoanfibolitos da Unidade Gentileza correspondem, em sua maioria, à andesitos e andesitos basálticos, com afinidades toleítica e cálcio-alcalina, enquanto que as rochas estudadas da Unidade Novo Gosto correspondem a protólitos basálticos de afinidade toleítica.

Os dados geoquímicos dos ortoanfibolitos da Unidade Novo Gosto sugerem a existência de dois grupos de protólitos ígneos: um denominado de alto-Ti, caracterizado por teores de $\mathrm{TiO} 2>$ $2 \%$, acompanhados por concentrações mais elevadas em P205, HFSE e $\sum$ ETR quando comparados ao segundo grupo; o segundo grupo, denominado de baixo-Ti, é marcado por baixos teores de $\mathrm{TiO} 2$ $<1,19 \%$, P2O5 < 0,01\%, HFSE e $\sum$ ETRs.

Os ortoanfibolitos da Unidade Gentileza possuem concentrações de LILE, HFSE e ETRs, em média, 1,5 a 3 vezes maiores que os dos ortoanfibolitos da Unidade Novo Gosto, apesar de possuírem teores de Ti semelhantes ao grupo alto-Ti.

Os dados obtidos nos diagramas discriminantes Zr - Z/Y (Pearce \& Norry, 1979), Ti - Zr (Pearce, 1996), V-Ti-Sm (Vermeesch, 2006), Ti/V-Zr/ $\mathrm{Sm}-\mathrm{Sr} / \mathrm{Nd}$ (Wang et al., 2016), Nb/Yb - Th/Yb (Pearce, 2008) e NbN - ThN (Saccani, 2015), aliados à presença de anomalias negativas de $\mathrm{Nb}, \mathrm{Ta}, \mathrm{Ti} \mathrm{e}$ $\mathrm{P}$ em diagramas multi-elementares normalizados e padrões de enriquecimento de ETRL em relação aos ETRP, em ambos os ortoanfibolitos das unidades estudadas, permitem concluir que os protólitos ígneos dessas rochas foram formados em um ambiente intraplaca, possivelmente representado por um rifte continental, o que corrobora com a hipótese de Oliveira \& Tarney (1990), Nascimento (2005) e Oliveira et al. (2010). A presença de ro- chas básicas com teores contrastantes de Ti (baixo e alto-Ti) é comum em diversos Derrames Basálticos Continentais e reforça essa hipótese.

A interpretação dos dados geoquímicos sugere que os magmas primitivos que deram origem aos protólitos ígneos dos ortoanfibolitos estudados foram derivados de uma mistura, em diferentes proporções, entre reservatórios enriquecidos (E-MORB), com contribuição de componentes tipo OIB, sobretudo para a Unidade Gentileza. Razões $\mathrm{Nb} / \mathrm{La}$ e $\mathrm{Sm} / \mathrm{Nd}$ acompanhadas por correlações negativas entre $\mathrm{La} / \mathrm{Sm}$ - $\mathrm{Nb} / \mathrm{La}$ sugerem a participação, de diferentes graus, de contaminação crustal na geração dos protólitos ígneos de ambas as unidades. Dados de $\mathcal{E N d}(\mathrm{t})$ negativos a levemente positivos (Tab. 4), obtidos por Nascimento (2005) para as rochas estudadas, corroboram com esta hipótese.

Anomalias negativas de $\mathrm{Nb}$, Ta e Ti observadas nas assinaturas das rochas de ambas as unidades qualificam estas como basaltos continentais semelhantes a arco (arc-like continental basalts), e podem ter sido geradas por modificações no manto litosférico subcontinental por subducção prévia e/ou por contaminação crustal.

Trabalhos futuros, envolvendo o detalhamento da composição isotópica dessas rochas, poderão auxiliar na avaliação de heterogeneidades mantélicas e confirmar as hipóteses desenvolvidas para a evolução petrogenética e a atuação de processos de assimilação/contaminação crustal na geração e evolução dos ortoanfibolitos das unidades Novo Gosto e Gentileza.

Agradecimentos. Os autores agradecem a CAPES, pela bolsa de mestrado, e ao CNPq pelo financiamento através dos projetos de pesquisa (processos: $461930 / 2014-5$ e 458432/2014-8). Os autores expressam igualmente os agradecimentos às críticas e sugestões dos revisores.

\section{Referências}

Agrawal, S., Guevara, M. \& Verma, S.P. 2008. Tectonic discrimination of basic and ultrabasic rocks through log-transformed ratios of immobile trace elements. International Geology Review, 50: 1057-1079. 
Barreto, C.J.S., Lafon, J.M., Lima, E.F. \& Sommer, C.A. 2016. Geochemical and $\mathrm{Sr}-\mathrm{Nd}-\mathrm{Pb}$ isotopic insight into the low-Ti basalts from southern Paraná Igneous Province, Brazil: the role of crustal contamination. International Geology Review, 58 (11): 1324-1349.

Bezerra, F.H.R. 1992. Geologia e evolução petrológica do Complexo Gabróico Canindé do São Francisco e rochas adjacentes (Sergipe e Alagoas). Brasília, 220p. Dissertação de Mestrado, Programa de Pós-graduação em Geologia, Instituto de Geociências, Universidade de Brasília.

Brito, R.S.C., Pimentel, M.M., Wharto, J.A., Dantas, E.L., Seixas, S.R. \& Morais, L.C. 2006. Braziliano-Panafrican Sm-Nd and Ar-Ar dating results from the Canindé do São Francisco gabbrosSergipano Belt, Brazil. In: SOUTH AMERICAN SYMPOSIUM ON ISOTOPE GEOLOGY, 5., 2006, Punta del Este. Short Papers... Punta del Este, SSAGI, v.1, p.58-60.

Brito Neves, B.B., Sial, A.N. \& Albuquerque, J.P.T. 1977. Vergência centrífuga residual no Sistema de Dobramentos Sergipano. Revista Brasileira de Geociências, 7(2): 102-114.

Chandrasekharam, D., Santo, A.P., Capaccioni, B., Vaselli, O., Alam, M. A., Manetti, P. \& Tassi, F. 2009. Volcanological and petrological evolution of Barren Island (Andaman Sea, Indian Ocean). Journal of Asian Earth Science, 35: 469-487.

Condie, K.C. 1993. Chemical composition and evolution of the upper continental crust: Contrasting results from surface samples and shales. Chemical Geology, 104(1-4): 1-37.

Condie, K.C. 2001. Mantle Plumes and Their Record in Earth History. London, Cambridge University Press, 326p.

Condie, K.C. \& Selverstone J. 1999. The crust of the Colorado Plateau: new views of an old arc. Journal of Geology, 107: 387-397.

Davison, I. \& Santos, R.A. 1989. Tectonic evolution of the Sergipano Fold Belt, NE Brazil, during the Brasiliano Orogeny. Precambrian Research, 45: 319-342.

D’el-Rey Silva, L.J.H. 1995. Tectonic Evolution of the Sergipano Belt, NE Brazil. Revista Brasileira de Geociências, 25(4): 315-332.

Dostal, J., Dupuy, C., Carron, J.P., Dekerneizon, M.L. \& Maury, R.C. 1983. Partition-Coefficients of
Trace-Elements - Application to Volcanic-Rocks of St-Vincent, West-Indies. Geochimica et Cosmochimica Acta, 47(3): 525-533.

Ernst, W.G., Hacker, B.R., Barton, M.D. \& Sen, G. 1991. Igneous petrogenesis of magnesian metavolcanic rocks from the central Klamath Mountains, northern California. Geological Society of America Bulletin, 103: 56 - 72.

Hawkesworth, C.J., Lightfoot, P.C., Fedorenko, V.A., Blake, S., Naldrett, A.J., Doherty, W. \& Gorbachev, N.S. 1995. Magma differentiation and mineralisation in the Siberian continental flood basalts. Lithos, 34: 61-88.

Humphrey, F.L. \& Allard, G.0. 1968. The Propriá Geosyncline, a newly recognized Precambrian tectonic province in the Brazilian shield. In: XXIII INTERNATIONAL GEOLOGICAL CONGRESS, 23., 1968, Prague. Anais... Prague, v.4, p.123-139.

Irvine, T.N. \& Baragar, W.R.A. 1971. A guide to the chemical classification of the common volcanic rocks. Canadian Journal of Earth Sciences, 8: 523-548.

Ivanov, A., Demonterova, E., Rasskazov, S. \& Yasnygina, T. 2008. Low-Ti melts from the southeastern Siberian Traps Large Igneous Province: evidence for a water-rich mantle source? Journal of Earth System Science, 117: 1-21.

Jardim de Sá, E.F., Moraes, J.A.C. \& Silva, L.J.H.D. 1986. Tectônica tangencial na Faixa Sergipana. In: CONGRESSO BRASILEIRO DE GEOLOGIA, 34., 1986, Goiânia. Anais... Goiânia, SBG, v.3, p.1246.

Jensen L.S. 1976. A new cation plot for classifying subalkalic volcanic rocks. Ontario, Division of Mines Miscllaneous Paper, 66: 1-22.

Jourdan, F., Bertrand, H., Schärer, U., Blichert-Toft, J., Féraud, G. \& Kampunzu, A.B. 2007. Major and trace element and $\mathrm{Sr}, \mathrm{Nd}, \mathrm{Hf}$, and $\mathrm{Pb}$ isotope compositions of the Karoo Large Igneous Province, Botswana-Zimbabwe: lithosphere vs mantle plume contribution. Journal of Petrology, 48: 1043-1077.

Khalifa, I.H., El-Bialy, M. \& Hassan, D.M. 2011. Petrologic and geochemical characterization and mineralization of the metavolcanic rocks of the Heib Formation, Kid Metamorphic Complex, Sinai, Egypt. Geoscience Frontiers, 2(3): 385-402. Li, Y., Brouwer, F.M., Xiao, W., Wang, K.L., Lee, Y.H., 
Luoa, B., Su, Y. \& Zheng, J. 2017. Subduction-related metasomatic mantle source in the eastern Central Asian Orogenic Belt: Evidence from amphibolites in the Xilingol Complex, Inner Mongolia, China. Gondwana Research, 43: 193-212.

Li, Z.X., Bogdanova, S.V., Collins, A.S., Davidson, A., De Waele, B., Ernst, R.E., Fitzsimons, I.C.W., Fuck, R.A., Gladkochub, D.P., Jacobs, J., Karlstrom, K.E., Lu, S., Natapov, L.M., Pease, V., Pisarevsky, S.A., Thrane, K. \& Vernikovsky, V. 2008. Assembly, configuration, and break-up history of Rodinia: a synthesis. Precambrian Research, 160: 179-210.

McDonough, W.F. \& Sun, S.S. 1995. The composition of the Earth. Chemical Geology, 120: 223253.

McKenzie, D. \& O’Nions, R.K. 1991. Partial melt distributions from inversion of rare Earth element concentrations. Journal of Petrology, 32: 10211091.

Melluso, L., Barbieri, M. \& Beccaluca, L. 2004. Chemical evolution, petrogenesis, and regional chemical correlations of the flood basalt sequence in the central Deccan Traps, India. Journal of Earth System Science, 126(2): 587-603.

Menezes Leal, A.B., Paul, D., Silveira, W.P., Bastos Leal, L.R., Cruz, S.C.P. \& Santos, J.P. 2008. Geoquímica das rochas meta-vulcânicas máficas do greenstone belt de Riacho de Santana, Bahia, Brasil. Revista Brasileira de Geociências, 38(3): 476-487.

Meschede, M. 1986. A method of discriminating between different types of mid-ocean ridge basalts and continental tholeiites with the Nb-Zr-Y diagram. Chemical Geology, 56: 207-218.

Mincato, R.L. 2000. Metalogenia dos elementos do grupo da platina com base na estratigrafia e geoquímica da Província Ígnea Continental do Paraná. Campinas, 172p. Tese de Doutorado, Instituto de Geociências, Programa de Pós-Graduação em Geociências, Universidade Estadual de Campinas.

Nascimento, R.S. 2005. Domínio Canindé, Faixa Sergipana, Nordeste do Brasil: um estudo geoquímico e isotópico de uma seqüência de rifte continental neoproterozoico. Campinas, 159p. Tese de Doutorado, Instituto de Geociências, Programa de Pós-Graduação em Geociências,
Universidade Federal de Campinas.

Nascimento, A.F., Andrade J.O., Liz, L.C.C., Liz, J.D. \& Goes, R.M. 2017. Investigação das misturas de magmas do magmatismo bimodal da Unidade Gentileza, Domínio Canindé, Faixa de Dobramentos Sergipana, NE-Brasil. In: SIMPÓSIO DE GEOLOGIA DO NORDESTE, 27., 2017, João Pessoa. Anais... João Pessoa. p. 447. Disponível em: <http://www.geologiadonordeste.com.br/ safetyarea/v3.0/trabalhos/resumo_pdf/447. pdf $>$. Acesso em: 15 jan. 2018.

Oliveira, E.P. \& Tarney, J. 1990. Petrogenesis of the Canindé do São Francisco complex: a major late Proterozoic gabbroic body in the Sergipano fold belt, NE Brazil. Journal South American Earth Science, 3: 125-140.

Oliveira, E.P., Toteu, S.F., Araújo, M.N.C., Carvalho, M.J., Nascimento, R.S., Bueno, J.F., McNaughton, N.J. \& Basilici, G. 2006. Geologic correlation between the Neoproterozoic Sergipano belt (NE Brazil) and the Yaounde belt (Cameroon, Africa). Journal of African Earth Sciences, 44: 470478.

Oliveira, E.P., Windley, B.F. \& Araújo, M.N.C. 2010. The Neoproterozoic Sergipano orogenic belt, NE Brazil: a complete plate tectonic cycle in western Gondwana. Precambrian Research, 181: 64-84.

Oliveira, E.P., Bueno, J.F., McNaughton, N.J., Silva Filho, A.F., Nascimento, R.S. \& Donatti-Filho, J.P. 2015. Age, composition, and source of continental arc- and syn-collision granites of the Neoproterozoic Sergipano Belt, Southern Borborema Province, Brazil. Journal of South American Earth Sciences, 44: 1-24.

Passos, L.H. 2016. Caraterização petrográfica, química mineral e geotermobarometria de rochas da Unidade Novo Gosto, Domínio Canindé, Faixa de Dobramentos Sergipana. Brasília, 225p. Dissertação de Mestrado, Programa de Pós-Graduação em Geologia, Instituto de Geociências, Universidade de Brasília.

Pearce, J.A. 1982. Trace element characteristics of lavas from the destructive plate boundaries. In: Thorpe, R.S. (Ed.). Andesites: Orogenic Andesites and Related Rocks. London, John Wiley \& Sons, p. 525-548.

Pearce, J.A. 1996. A user's guide to basalt discrimi- 
nation diagrams. Geological Association of Canada Special Publication, 12: 79-113.

Pearce, J.A. 2008. Geochemical fingerprinting of oceanic basalts with applications to ophiolite classification and the search for Archean oceanic crust. Lithos, 100: 14-48.

Pearce, J.A. 2014. Immobile Elements Fingerprinting of Ophiolites. Elements, 10: 101-108.

Pearce, J.A. \& Cann, J.R. 1973. Tectonic setting of basic volcanic rocks determined using trace element analyses. Earth and Planetary Science Letters, 19: 290-300.

Pearce, J.A. \& Norry, M.J. 1979. Petrogenetic implications of $\mathrm{Ti}, \mathrm{Zr}, \mathrm{Y}$ and $\mathrm{Nb}$ variations in volcanic rocks. Contributions to Mineralogy and Petrology, 69: 38-47.

Peate, D.W. \& Hawkesworth, C.J. 1996. Lithospheric to asthenospheric transition in low-Ti flood basalts from southern Parana, Brazil. Chemical Geology, 127:1-24.

Rocha-Júnior, E.R.V., Marques, L.S., Babinski, M., Nardy, A.J.R., Figueiredo, A.M.G. \& Machado, F.B. 2013. Sr-Nd-Pb isotopic constraints on the nature of the mantle sources involved in the genesis of the high-Ti tholeiites from northern Paraná Continental Flood Basalts (Brazil). Journal of South American Earth Sciences, 46: 9-25.

Rudnick, R.L. \& Gao, S. 2003. Composition of the continental crust. In: Holland, H.D. \& Turekian, K.K. (Ed.). Treatise on Geochemistry. Oxford, Elsevier-Pergamon, p. 1-64.

Saccani, E. 2015. A new method of discriminating different types of post-Archean ophiolitic basalts and their tectonic significance using Th -Nb and Ce-Dy-Yb systematics. Geoscience Frontiers, 6: 481-501.

Seixas, S.R.M. \& Moraes, L.C. 2000. The Canindé Domain: its different gabbroic rocks. In: INTERNATIONAL GEOLOGICAL CONGRESS, 31., 2000, Rio de Janeiro. Anais...p.6.

Sheraton, J.W. 1984. Chemical changes associated with high-grade metamorphism of mafic rocks in the east Antarctic shield. Chemical Geology, 47: 135-157.

Shervais, J.W. 1982. Ti-V plots and the petrogenesis of modern ophiolitic lavas. Earth and Planetary Science Letters, 59: 101-118.

Silva Filho, M.A. 1976. A suíte ofiolítica da Geos- sinclinal de Propriá. In: SBG, CONGRESSO BRASILEIRO DE GEOLOGIA, 29., 1976, Ouro Preto. Anais...Ouro Preto, SBG, p. 51.

Silva Filho M.A. 1998. Arco vulcânico Canindé-Marancó e a Faixa Sul-Alagoana: sequências orogênicas Mesoproterozóicas. In: CONGRESSO BRASILEIRO DE GEOLOGIA, 50., 1998, Belo Horizonte. Anais...Belo horizonte, SBG, p. 16.

Sun, S.S. \& McDonough, W.F. 1989. Chemical and Isotopic systematics of oceanic basalts, implications for mantle composition and processes. Geological Society of London Special Publication, 42: 313-345.

Taylor, S.R. \& McLennan, S.M. 1985. The continental crust: its composition and evolution. Oxford, Blackwell Scientific Publication, 312p.

Texeira, L.R., Lima, E.S., Neves, J.P., Santos, R.A., Santiago, R.C. \& Melo, R.C. 2014. Mapa Geológico e de Recursos Minerais do Estado de Sergipe, Salvador, CPRM - Serviço Geológico do Brasil. Escala 1:250.000.

Trompette R. 1994. Geology of Western Gondwana (2000-500 Ma): Pan-African-Brasiliano aggregation of South America and Africa. Rotterdam, Balkema, p. 350.

Verma, S.P. \& Agrawal, S. 2011. New tectonic discrimination diagrams for basic and ultrabasic volcanic rocks through log-transformed ratios of high field strength elements and implications for petrogenetic processes. Revista Mexicana Ciencias Geológicas, 28: 24-44.

Verma, S.K. \& Oliveira, E.P. 2015. Tectonic setting of basic igneous and metaigneous rocks of Borborema Province, Brazil using multi-dimensional geochemical discrimination diagrams. Journal of South American Earth Sciences, 58: 309-317.

Verma, S.P., Guevara, M. \& Agrawal, S. 2006. Discriminating four tectonic settings: five new geochemical diagrams for basic and ultrabasic volcanic rocks based on log-ratio transformation of major-element data. Journal of Earth Systems Science, 115: 485-528.

Vermeesch, P. 2006. Tectonic discrimination diagrams revisited. Geochemistry Geophysics Geosystems, 7: 1-55.

Wang, X.C., Li, Z.X., Li, J., Pisarevsky, S.A. \& Wingate, M.T.D. 2014. Genesis of the 1.21 Ga Marnda Moorn large igneous province by plume-lithos- 
phere interaction. Precambrian Research, 241: 85-103.

Wang, X.C., Wilde, A.S., Li, Q.L. \& Yang, Y.N. 2015. Continental flood basalts derived from the hydrous mantle transition zone. Nature Communication, 6:7700.

Wang X.C., Wilde, S.A., Xu, B. \& Pang, C.J. 2016. Origin of arc-like continental basalts: Implications for deep-Earth fluid cycling and tectonic discrimination. Lithos, 261: 5-45.

Weaver, B.L. \& Tarney, J. 1981. Chemical changes during dyke metamorphism in high-grade basement terrains. Nature, 289: 47-49.

Wilson, M. 1989. Igneous Petrogenesis a global tectonic approach. London, Springer, 466p.

Wood, D.A. 1980. The application of a Th-Hf-Ta diagram to problems of tectonomagmatic classification and to establishing the nature of crustal contamination of basaltic lavas of the British Tertiary volcanic province. Earth and Planetary Science Letters, 50: 11-30.

Xia, L.Q. 2014. The geochemical criteria to distinguish continental basalts from arc related ones. Earth-Science Reviews, 139: 195-212. 